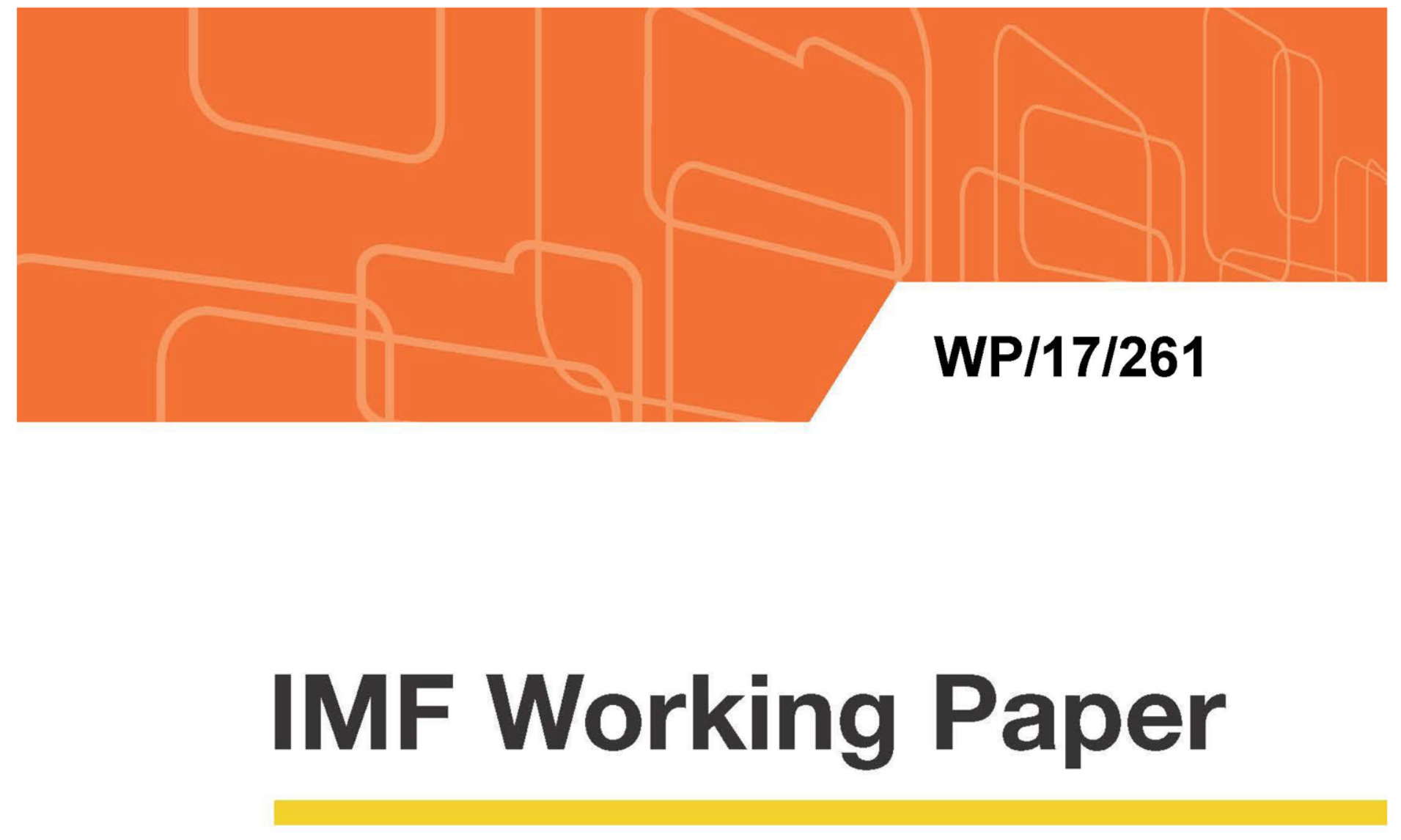

\title{
Asymmetries in the Coordinated Direct Investment Survey: What Lies Behind?
}

by Emma Angulo and Alicia Hierro

IMF Working Papers describe research in progress by the author(s) and are published to elicit comments and to encourage debate. The views expressed in IMF Working Papers are those of the author(s) and do not necessarily represent the views of the IMF, its Executive Board, or IMF management.

$$
\text { I N T E R N A T I O N A L M O N E T A R Y F U N D }
$$




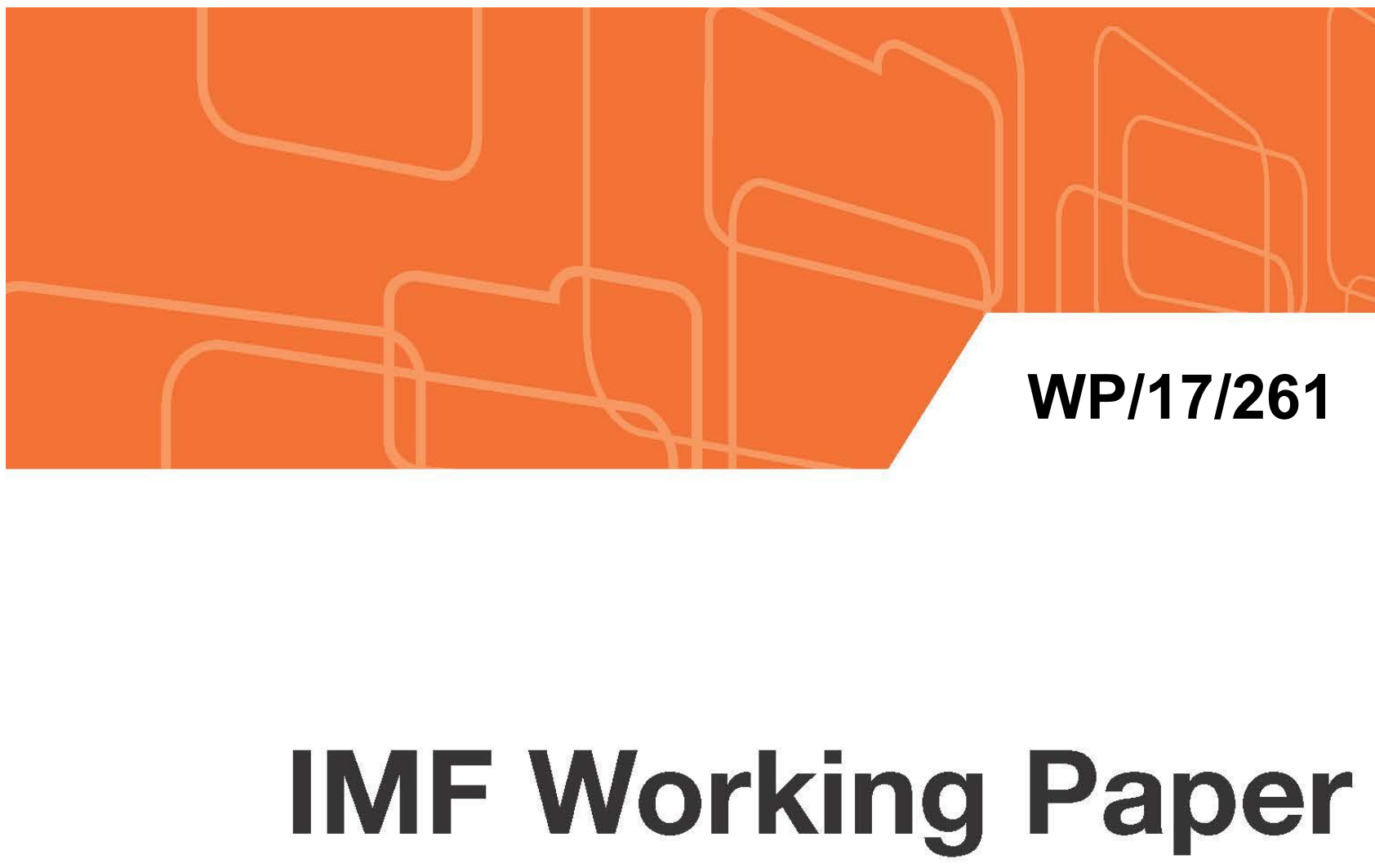

\section{Asymmetries in the Coordinated Direct Investment Survey: What Lies Behind?}

by Emma Angulo and Alicia Hierro

IMF Working Papers describe research in progress by the author(s) and are published to elicit comments and to encourage debate. The views expressed in IMF Working Papers are those of the author(s) and do not necessarily represent the views of the IMF, its Executive Board, or IMF management.

I N T E R N A T I O N A L M O N E T A R Y F U N D 


\title{
IMF Working Paper
}

Statistics Department

\section{Asymmetries in the Coordinated Direct Investment Survey: What Lies Behind?}

\author{
Prepared by Emma Angulo and Alicia Hierro ${ }^{1}$ \\ Authorized for distribution by Mr. Carlos Sánchez-Muñoz
}

November 2017

\begin{abstract}
IMF Working Papers describe research in progress by the author(s) and are published to elicit comments and to encourage debate. The views expressed in IMF Working Papers are those of the author(s) and do not necessarily represent the views of the IMF, its Executive Board, or IMF management.
\end{abstract}

\begin{abstract}
This paper analyzes asymmetries in direct investment positions reported in the Coordinated Direct Investment Survey (CDIS) following a top down approach. First, it examines asymmetries at global level; second, it examines asymmetries between CDIS reported and derived data for individual economies; and third, the paper analyzes data at bilateral economy level.
\end{abstract}

Then, the paper explores seven main reasons for asymmetries, including those arising even when economies follow international standards.

Finally, the paper includes a section on addressing bilateral asymmetries and concludes with specific planned actions to reduce asymmetries, including initiatives led by international organizations.

JEL Classification Number: F21, F23, F30.

Keywords: CDIS, Direct Investment, Bilateral Asymmetries

Author's E-Mail Address: eangulo@,imf.org; ahierro@imf.org

\footnotetext{
${ }^{1}$ We are thankful to Eduardo Valdivia-Velarde for his useful suggestions and comments.
} 
Abstract $\underline{2}$

I. Introduction $\underline{5}$

II. CDIS Results for the Total World.... $\underline{6}$

A. Total Outward Direct Investment vs. Total Inward Direct Investment .................... $\frac{6}{8}$

B. Total Direct Investment Assets vs. Total Direct Investment Liabilities in the IIP ... $\underline{8}$

III. CDIS Reported vs CDIS Derived Data for Individual Economies

A. Top Ten Differences Between Reported and Derived Data ................................10

B. Top Differences in Inward Reported and Derived: Analysis for Selected

Economies

C. Top Differences in Outward Reported and Derived: Analysis for Selected

Economies.

IV. CDIS Results by Compiling Economy $\underline{13}$

A. Smallest Bilateral Asymmetries .............................................................. 13

B. Largest Bilateral Asymmetries .................................................................

V. Main Reasons for Bilateral Asymmetries .... 15

A. Asymmetries Arising from the Recording of Positions Between Fellow Enterprises when the Ultimate Controlling Parent (UCP) is Nonresident.................................16

B. Different Coverage, Lack or Partial Coverage ................................................. $\frac{18}{23}$

C. Different Geographic Allocation: Immediate vs. Ultimate Investing Economy...... $\underline{23}$

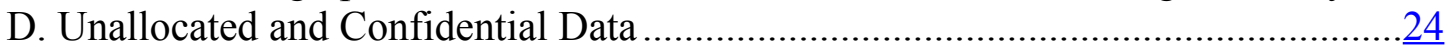

E. Methodological Issues ..................................................................... 25

F. Data Sources and Estimation Techniques........................................................29

G. Criteria for Identifying Entities in a Direct Investment Relationship ...................

VI. Addressing Bilateral Asymmetries .......................................................................... 31

A. Compliance with Recommended Guidelines for Recording CDIS Data .................

B. Reducing the Reporting of Confidential and Unallocated Data by Counterpart

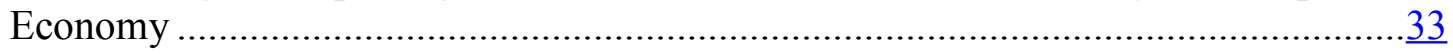

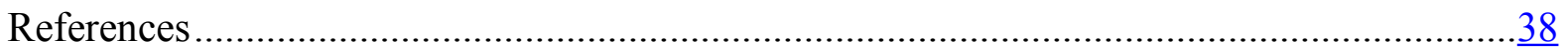

Tables

1. Top Ten Differences Inward/Inward Derived.........................................................10

2. Top Ten Differences Outward/Outward Derived ...................................................11

3. Twenty Smallest Bilateral Asymmetries as of End-2015 ........................................14

4. Twenty Largest Bilateral Asymmetries as of End-2015 ...........................................15

5A. Bilateral Asymmetries from Total Direct Investment as of end-2015 .........................17

5B. Bilateral Asymmetries in Total Direct Investment as of end-2015 .............................18

6. Total Direct Investment Positions with Split by Resident SPEs - OECD Data .................19

7. Top 15 Economies that Did Not Report 2015 Inward/Outward CDIS ..............................21 


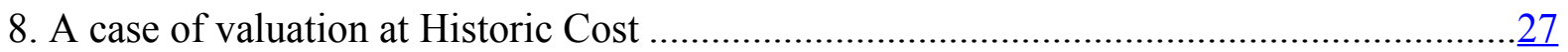

9. Asymmetries when the Ultimate Controlling Parent is Nonresident for Both ....................41

10. Asymmetries when One Economy Collects Data from LEGs as of end-2015 ……...........43

11-A. Inward Direct Investment Positions - Economies Reporting 2015 Data for Fellow

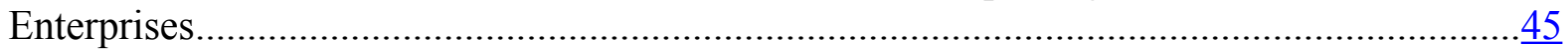

11B. Outward Direct Investment Positions - Economies Reporting 2015 Data for Fellow

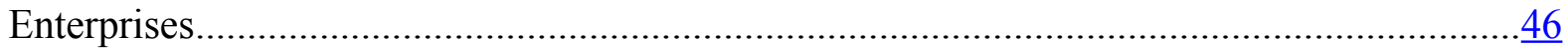

12-A. Not Specified over Total Inward Direct Investment for Individual Economies.............47

12-B. Not Specified over Total Outward Direct Investment for Individual Economies .......... 47

Figures

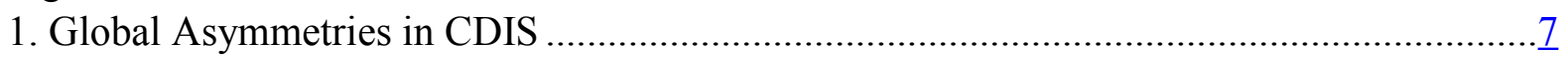

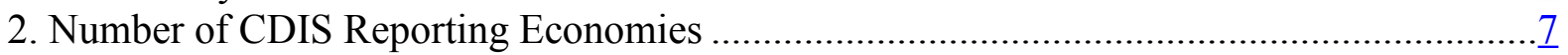

3. Outward vs Inward by Instrument in the CDIS …….................................................

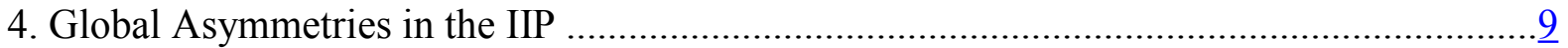

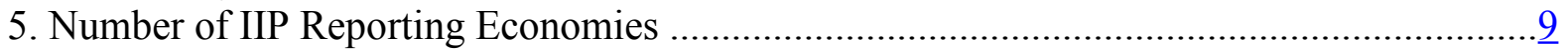

6. DI Assets vs DI Liabilities by Instrument in the IIP ......................................................

7. Number of Economies Including Real Estate Date in the DCIS .....................................23

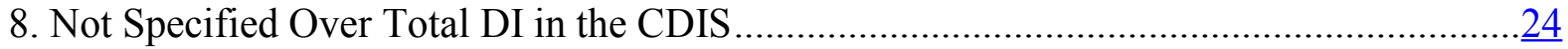

9. Primary Valuation Principle for Listed and Unlisted Equity .............................................26

10. Primary Valuation Principle for Debt Securities and Other Debt Instruments...................28

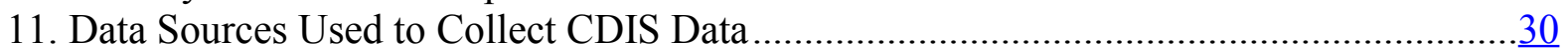

12. Methods to Estimate Date for Nonresponding Units ....................................................

13. Methods Used to Determine Direct Investment Relationships...........................................31

Annexes

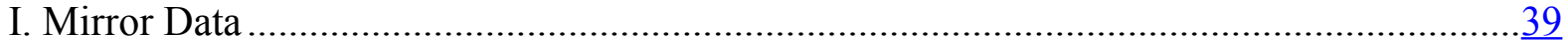

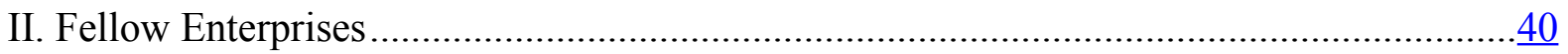

III. Asymmetries in Data Between Fellows ..................................................................

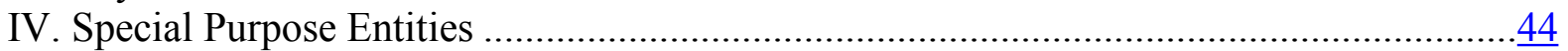

V. Economies Reporting Data on Fellow Enterprises to the CDIS .......................................45

VI. Top Economies Reporting Unallocated or Confidential Data ........................................47

VII. Information Included in the CDIS Metadata Questionnaire ……………………........... 48

VIII. Actions to Reduce Asymmetries .................................................................................49 


\section{INTRODUCTION}

The CDIS is a worldwide statistical data collection effort led by the IMF designed to improve the availability and quality of data on direct investment, both at overall level in the international investment position (IIP) and by immediate counterpart economy. The CDIS database presents detailed annual data on inward direct investment positions starting from data since end-2009 cross-classified by economy of immediate investor (direct investment into the reporting economy), and data on outward direct investment positions (direct investment abroad by the reporting economy) cross-classified by economy of immediate investment.

The structure of the CDIS database allows easy comparison of data reported by one economy and mirror data (obtained from all other counterpart reporting economies). Mirror data may be useful in highlighting data gaps or errors, and therefore where follow up efforts may prove beneficial.

The IMF is making continuous efforts to broaden participation in the CDIS as well as to improve the quality of the reported data. As part of these efforts, in May 2016, the IMF's Statistics Department (STA) conducted a project to raise awareness on (and to the extent feasible try to address) large bilateral asymmetries based on the 2015 CDIS release for end-2014 CDIS data, contacting a total of 47 CDIS participants.

STA conducted a similar project in 2013 based on the 2012 CDIS release with a more reduced scope (28 CDIS participants). ${ }^{2}$ Both exercises provided insights into the reasons for asymmetries. They also helped some economies detect errors and consider taking actions to further improve the quality of their direct investment data. Several economies have conducted recent studies triggered by these projects under the auspices of the IMF Committee on Balance of Payments Statistics (Committee). ${ }^{3}$ STA continues its efforts in the field of direct investment asymmetries in coordination with other international organizations.

This paper analyzes asymmetries in direct investment positions reported in CDIS following a top down approach. In the following three sections, it (i) examines asymmetries at global level; (ii) examines asymmetries between CDIS reported and derived data for individual economies; and (iii) analyzes data at bilateral economy level, by comparing data as reported by individual economies vis-a-vis their individual counterparts and considering main symmetries and main asymmetries. Lessons learned on the reasons for asymmetries and proposed ways to reduce bilateral asymmetries are presented in the last two sections of the paper.

\footnotetext{
${ }^{2}$ As a result of this work, STA posted a paper, "Coordinated Direct Investment Survey (CDIS): Project on Bilateral Asymmetries: June 2014".

${ }^{3}$ For specific studies on asymmetries see related $\underline{\text { Statistical Papers }}$ at the Committee's website.
} 


\section{CDIS ReSUlts FOR THE TOTAL WORLD}

This section examines asymmetries at global level; comparing total outward and total inward direct investment reported by all CDIS reporting economies and analyzing global asymmetries by instrument. The results are then compared with the global asymmetries obtained from direct investment assets vs. liabilities reported in the international investment position (IIP).

Direct investment positions are concentrated in equity, representing around 80 percent of the total direct investment, which raises awareness of the importance of applying consistent valuation methods for unlisted equity to reduce the bilateral asymmetries between counterpart economies. The global asymmetries in net equity are always positive, that is, total outward equity positions are always larger than total inward equity positions, and on the other hand, the asymmetries in net debt instruments are always negative, that is, total inward debt positions are always larger than total outward debt positions for the seven years covered in the CDIS. Assuming that inward direct investments positions are more accurate than outward positions, for both equity and debt instruments, this section concludes that equity investment abroad tends to be overestimated while debt investment positions abroad tends to be underestimated.

\section{A. Total Outward Direct Investment vs. Total Inward Direct Investment}

In principle, at a global level, total outward direct investment positions should be equal to total inward direct investment positions reported by all economies. However, in the CDIS database, there are differences between outward and inward reported totals because (i) not all economies participate in the CDIS, (ii) not all CDIS reporting economies provide outward data, and (iii) there are some bilateral asymmetries between reporting economies.

Figure 1 shows the differences between total outward and total inward direct investment positions reported by the CDIS participating economies. In most cases, the number of reporting economies, indicated in Figure 2, increases over the years and is always larger for inward than for outward (outward data are more difficult to compile and not relevant for some small economies). The global difference is particularly small in 2013, when the maximum number of participants is reached (76 for outward and 110 for inward) and the data could be considered "final" after two years of collecting revised data.

The sign of the differences is not homogenous; therefore, it cannot be deduced that there are missing values in one or the other component (inward or outward). These global asymmetries can be analyzed in more detail, assessing the asymmetries produced in the main components of the direct investment positions; equity and debt instruments.

Figure 3 presents the global asymmetries by instrument. The figure shows that, for all periods, the weight of the net equity component in the total direct investment is much higher than the weight of the net debt instruments (for outward, the weight of equity ranges from 84 
to 89 percent, and for outward it ranges from 77 to 81 percent). This results highlight the importance of applying a consistent valuation of unlisted equity. Compilers should apply the same valuation methods to reduce the bilateral asymmetries between counterpart economies.

Also, it shows that the asymmetries in net equity are always positive, therefore, the total amounts reported under outward-equity are always larger than the total amounts reported under inward-equity for the seven years covered by the CDIS. As the number of inward reporters is larger than the number of outward reporters, these asymmetries cannot be explained by missing reporters. The differences are likely due to the different valuation methods applied by compilers. The investments abroad are higher valued than the investment in the reporting economy where the information is easier to measure and tends to be more accurate. Therefore, in principle, investment in equity abroad (outward equity) tends to be overestimated.

On the other hand, Figure 3 also shows that the global asymmetries in net debt instrument positions are always negative, that is, the total amounts reported under outward-debt instruments are smaller than the total amounts reported under inward-debt instruments for the seven years covered by the CDIS. As the inward-debt instruments positions are more accurate, mainly due to the higher number of inward reporters and the better coverage of inward debt instruments. It can be assumed that investment in debt instruments abroad (outward debt instruments) tends to be underestimated.

Finally, Figure 3 also shows that the differences at instrument level are larger than the total asymmetries because positive differences in equity are compensated with negative differences in debt.
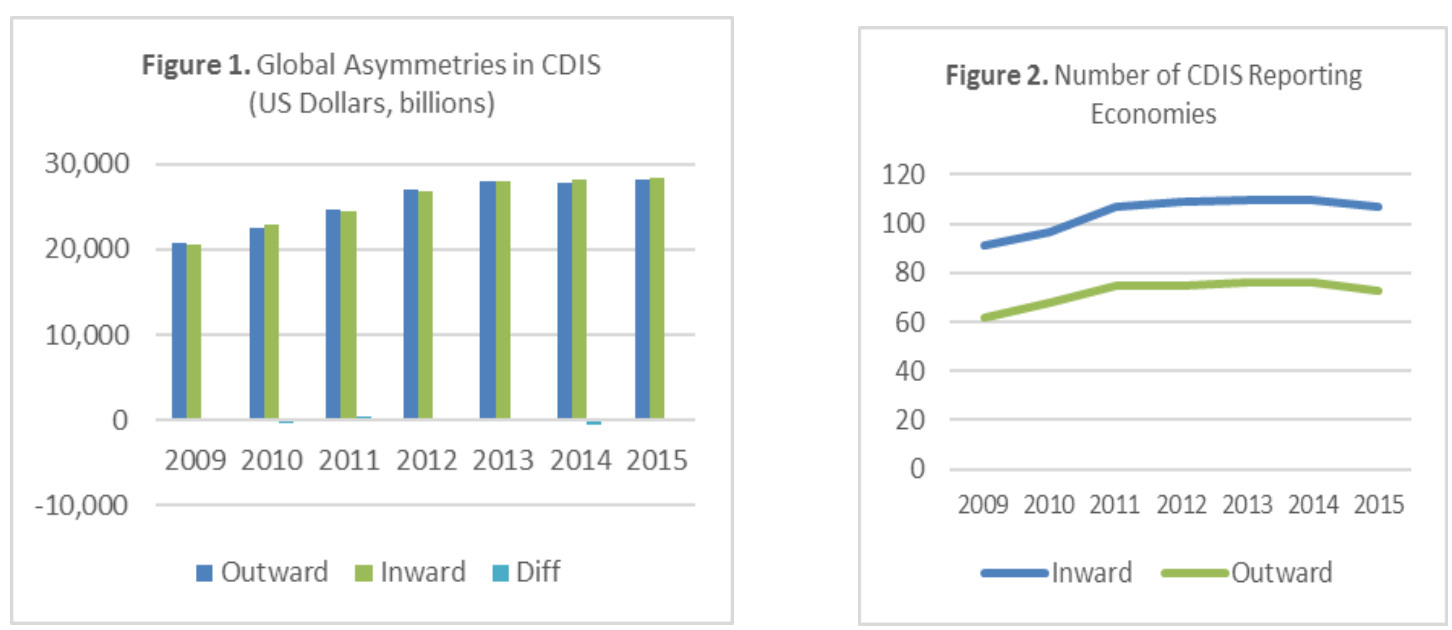
Figure 3. Outward vs Inward by Instrument in the CDIS

(US Dollars, billions)
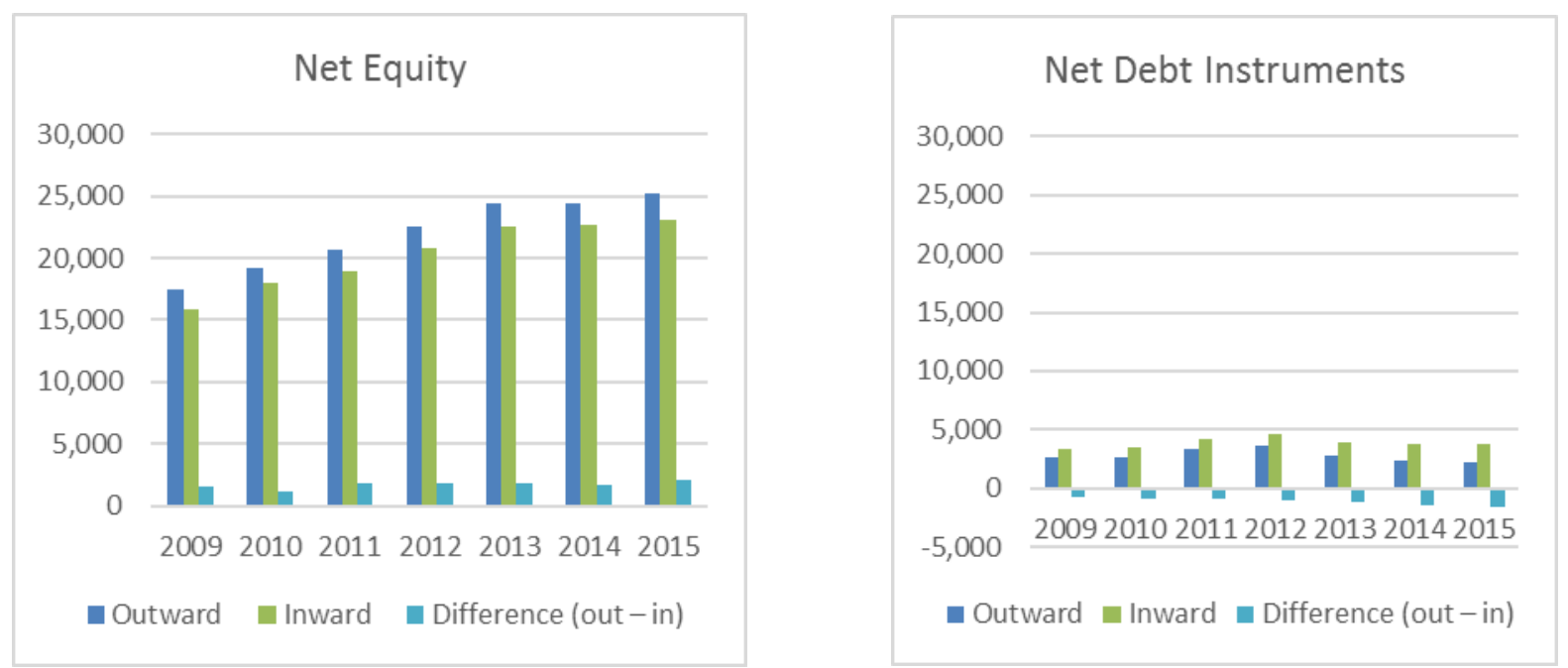

Source IMF's CDIS, 2016 release

\section{B. Total Direct Investment Assets vs. Total Direct Investment Liabilities in the IIP}

The values reported in the CDIS are different than the values reported in the direct investment component of the IIP due to three main reasons: (i) the number of economies reporting IIP data to STA is larger than the number of economies reporting CDIS data; (ii) direct investment data are presented on a net basis in the CDIS, following the directional principle, and on a gross basis in the IIP, following the assets/liabilities presentation; and (iii) the possibility of applying six different valuation methods for unlisted equity in the IIP, as a proxy for market value (para. 7.16 of BPM6), while, in the CDIS, unlisted equity should be valued at own funds at book value.

The number of economies compiling IIP data (see Figure 5) is larger than the number of economies participating in the CDIS because the IIP data are compiled on an aggregated basis and CDIS data must be provided broken down by counterpart economy, which is more difficult to compile.

The results shown in Figures $\mathbf{4}$ and $\mathbf{6}$ for the IIP are similar to those described in Figures $\mathbf{1}$ and 3 for the CDIS. The weight of the equity component in the total direct investment is also higher than the weight of the debt instruments, for both assets and liabilities, representing approximately 72 percent of the assets and 65 percent of the liabilities. Also, the asymmetries for equity are always positive and the asymmetries for debt instruments are always negative. Therefore, the previous findings are verified with these results. 

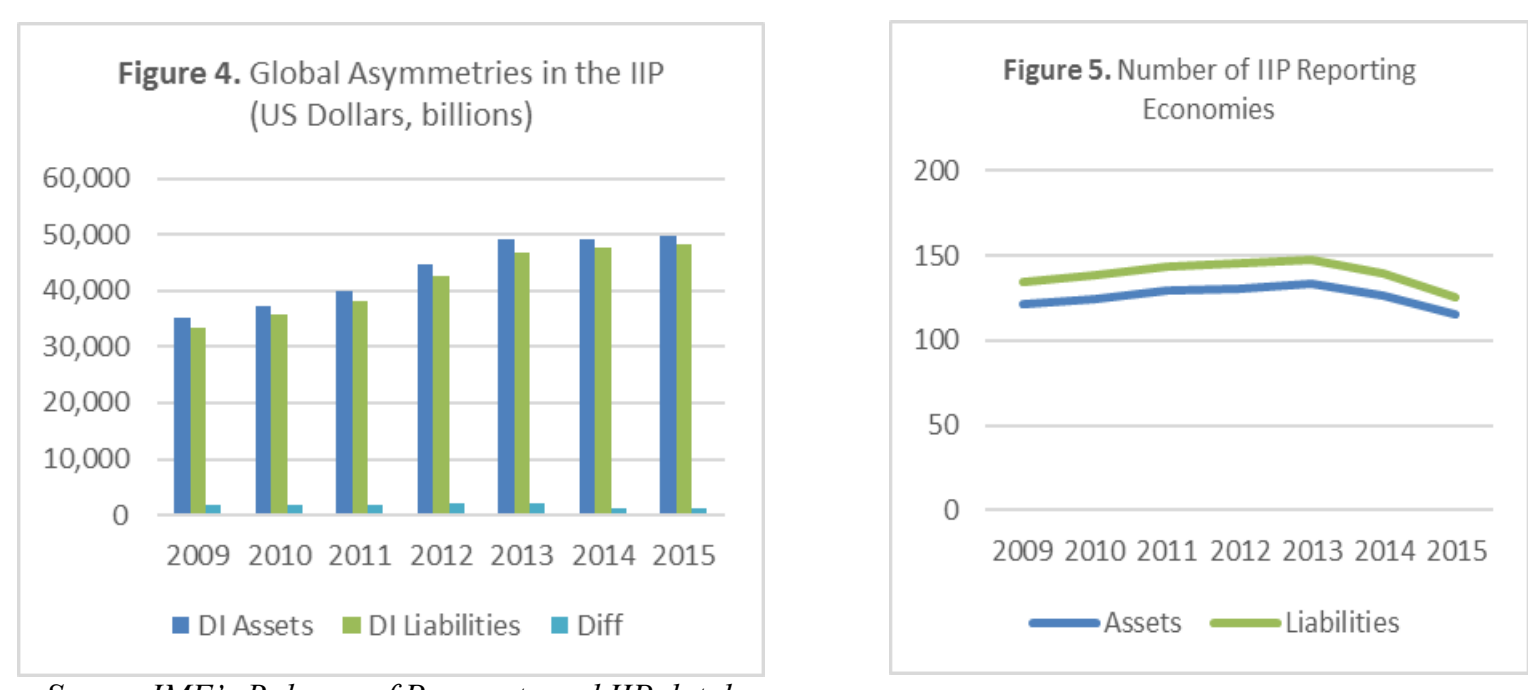

Source IMF's Balance of Payments and IIP database

Figure 6. DI Assets vs DI Liabilities by Instrument in the IIP

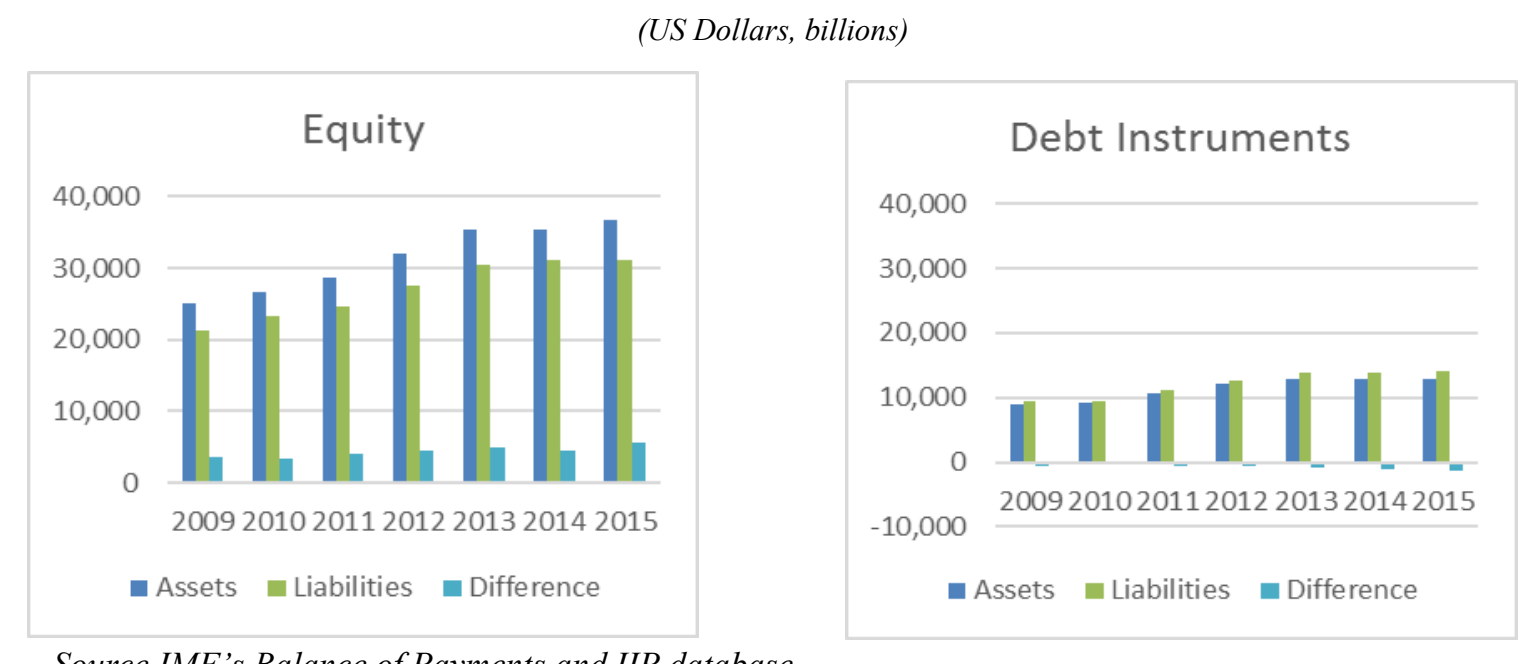

Source IMF's Balance of Payments and IIP database

\section{CDIS REPORTED VS CDIS DERIVED DATA FOR INDIVIDUAL ECONOMIES}

While the previous section examined asymmetries for the total world, this section focuses on asymmetries between reported and derived data for individual economies and discusses the usefulness and limitations of derived measures of direct investment (see more details in Annex I).

To this end, this section identifies the ten economies with the largest asymmetries between reported and derived data for inward and outward direct investment, respectively. The section further analyzes selected economies and identifies the reasons for the asymmetries.

Asymmetries between reported and derived data can be spread among several counterparts or concentrated in a few counterparts. Asymmetries can be explained due to missing data by the counterparts or to bilateral asymmetries. Some counterpart economies do not provide data 
either because they do not participate in the CDIS, or because the data provided are considered confidential, or fall below a reporting threshold. Mirror data are useful to cross check and verify countries' own estimates, to highlight data gaps or errors, and to identify areas for improvement. If reported data by a given economy are lower than derived data, it can suggest under coverage; therefore, asymmetries at bilateral level should be analyzed.

\section{A. Top Ten Differences Between Reported and Derived Data}

Tables 1 and 2 below show the top ten differences between CDIS reported and derived data for inward and outward direct investment, respectively. Inward data reported by one given economy are compared with outward data reported by its reporting counterparts (derived inward); and outward data reported by the given economy are compared with inward data reported by its reporting counterparts (derived outward).

Table 1. Top Ten Differences Inward/Inward Derived

(US Dollars, millions)

\begin{tabular}{|c|c|c|c|c|}
\hline 2015 & $\begin{array}{c}\text { Direct Investment } \\
\text { Inward } \\
\text { (reported) }\end{array}$ & $\begin{array}{l}\text { DI Inward Derived } \\
\text { (reported by } \\
\text { counterparts) }\end{array}$ & $\begin{array}{c}\text { Inward-Inward } \\
\text { Derived }\end{array}$ & $\%$ \\
\hline \multirow{5}{*}{$\begin{array}{r}\text { China, P.R.: Mainland } \\
\text { Netherlands } \\
\text { China, P.R.: Hong Kong } \\
\text { Luxembourg } \\
\text { Singapore }\end{array}$} & $2,579,564$ & $1,149,305$ & $1,430,259$ & $55 \%$ \\
\hline & $3,939,415$ & $2,567,917$ & $1,371,498$ & $35 \%$ \\
\hline & $1,394,580$ & 199,413 & $1,195,167$ & $86 \%$ \\
\hline & $3,271,769$ & $2,429,298$ & 842,471 & $26 \%$ \\
\hline & 869,572 & 577,405 & 292,167 & $34 \%$ \\
\hline Mexico & 509,292 & 279,969 & 229,324 & $45 \%$ \\
\hline Mauritius & 269,105 & 72,144 & 196,961 & $73 \%$ \\
\hline Belgium & 455,366 & 662,433 & $-207,067$ & $-45 \%$ \\
\hline United States & $3,134,199$ & $3,886,610$ & $-752,411$ & $-24 \%$ \\
\hline United Kingdom & $1,554,303$ & $2,736,859$ & $-1,182,557$ & $-76 \%$ \\
\hline
\end{tabular}

Source IMF's CDIS, 2016 release

As shown in Table 1, while China, P.R. Mainland reported inward direct investment amounting to US\$2,580 billion at end-2015, all its CDIS counterparts reported outward investment in China P.R.: Mainland for only US\$1,149 billion (representing only 44 percent of the inward reported). These mirror data reported by all its counterparts can then be used as a measure of the derived inward. 
Table 2. Top Ten Differences Outward/Outward Derived

(US Dollars, millions)

\begin{tabular}{|c|c|c|c|c|}
\hline 2015 & $\begin{array}{c}\text { Direct Investment } \\
\text { Outward } \\
\text { (reported) }\end{array}$ & $\begin{array}{c}\text { DI Outward } \\
\text { Derived (reported } \\
\text { by counterparts) }\end{array}$ & $\begin{array}{c}\text { Outward- } \\
\text { Outward Derived }\end{array}$ & $\%$ \\
\hline Netherlands & $4,680,387$ & $2,863,149$ & $1,817,238$ & $39 \%$ \\
\hline Luxembourg & $3,829,107$ & $2,439,494$ & $1,389,613$ & $36 \%$ \\
\hline United States & $5,040,648$ & $4,058,409$ & 982,239 & $19 \%$ \\
\hline Germany & $1,376,181$ & $1,131,120$ & 245,061 & $18 \%$ \\
\hline Ireland & 887,510 & 645,808 & 241,702 & $27 \%$ \\
\hline Australia & 396,432 & 161,945 & 234,487 & $59 \%$ \\
\hline Russian Federation & 286,583 & 102,821 & 183,762 & $64 \%$ \\
\hline Italy & 467,300 & 306,831 & 160,469 & $34 \%$ \\
\hline Belgium & 446,237 & 616,707 & $-170,471$ & $-38 \%$ \\
\hline United Kingdom & $1,563,865$ & $2,226,308$ & $-662,443$ & $-42 \%$ \\
\hline
\end{tabular}

Source IMF's CDIS, 2016 release

\section{B. Top Differences in Inward Reported and Derived: Analysis for Selected Economies}

In the case of China, P.R.: Mainland, 44 percent of the difference in inward is explained by its counterpart China, P.R. Hong Kong, which reports a much lower amount of investment in China, P.R. Mainland (outward investment reported by Hong Kong in Mainland is US $\$ 608$ billion, versus US $\$ 1,239$ billion reported by Mainland as inward investment received from Hong Kong). In addition, 41 percent of the difference is explained because some of the main counterparts do not report outward data (for example, British Virgin Islands accounts for US $\$ 328$ billion followed by Singapore with US\$111 billion, representing respectively 23 and 8 percent of the total difference). There are also some smaller differences acting in the opposite direction (meaning that inward reported by Mainland is lower than mirror data reported by counterpart); South Africa is the most significant case, but represents only 4 percent of the total difference in absolute terms.

For the Netherlands, differences in inward are spread among many countries, the most relevant ones correspond to United Kingdom (US\$189 billion), Luxembourg (US\$187billion), and Switzerland (US\$134 billion) representing, respectively 14, 14, and 10 percent of the total difference. In addition, 29 percent of the difference is explained because some of its main counterparts do not report outward data (Bermuda accounts for US $\$ 291$ billion followed by Cayman Islands with US $\$ 49$ billion). There are also some smaller differences acting in the opposite direction (meaning that inward reported by the Netherlands is lower than mirror data reported by its counterpart); United States is the most significant case, but represents only 5 percent of the total difference in absolute terms.

In the case of China, P.R. Hong Kong, however, around 95 percent of the difference in inward data is explained because its main counterpart economies do not report outward data 
(British Virgin Islands and China, P.R.: Mainland account for US\$552 and US\$349 billion respectively, followed by Cayman Islands and Bermuda with US\$85 and US\$74 billion).

For the United Kingdom, the difference has opposite sign that in the previous cases, meaning that reported inward data is much lower that the derived inward data. Main difference is with Luxembourg (-US\$593 billion), representing 50 percent of the total asymmetry, followed by the Netherlands and the United States, with differences of -US\$263 and -US\$160 billion, representing respectively 22 and 13 percent of the total difference. There are also some differences acting in the opposite direction (meaning that inward reported is higher than inward derived); this is mostly due to some counterparts not reporting outward data (mainly Bermuda, Cayman Islands, and British Virgin Islands with differences representing respectively 6,3 , and 2 percent of the total difference in absolute terms).

\section{Top Differences in Outward Reported and Derived: Analysis for Selected Economies}

For the Netherlands, 74 percent of the difference in outward data is explained due to different figures reported by its counterparts and 23 percent is explained by missing reporters. Differences are spread among many countries and most relevant ones correspond to United Kingdom (US\$263 billion), the United States (US\$232 billion), and Luxembourg (US $\$ 188$ billion) representing respectively 14,13 , and 10 percent of the total difference. In addition, 23 percent of the difference in outward data is explained because main counterparts do not report inward data (Bermuda accounts for US $\$ 165$ billion followed by Puerto Rico with US\$109 billion, representing respectively 9 and 6 percent of the difference).

In the case of Luxembourg, 49 percent of the difference in outward data is explained because its counterpart the United States reports a much lower figure for the corresponding mirror data (inward reported by the United States as received from Luxemburg is US $\$ 328$ billion, versus US $\$ 1,011$ billion reported by Luxembourg as outward investment in the United States). A similar situation applies for United Kingdom, accounting for 43 of the difference (inward reported by United Kingdom as received from Luxemburg is US $\$ 105$ billion, versus US\$698 billion reported by Luxembourg as invested in United Kingdom). Only 12 percent of the difference in outward data is explained because main counterparts do not report inward data, Gibraltar and Bermuda being most significant ones (representing each around 5 percent of the difference). In some other cases, there are differences that have opposite sign (this is, its counterparts are reporting higher figures in mirror data, for example the Netherlands and Germany, accounting for 13 and 6 percent of the total difference in absolute terms).

In the case of United States, a significant part of the difference in outward is explained because main counterparts do not report inward data; Bermuda and Cayman Islands represent 27 and 26 of the difference respectively. In addition, the difference is also explained due to lower figures reported by its counterparts. Differences are spread among many countries; the 
most relevant one corresponds to United Kingdom (US\$160 billion), representing 16 percent of the difference, followed by Canada and the Netherlands with differences of 7 percent each. In some other cases, there are differences that have opposite sign (the counterparts are reporting higher figures in mirror data, than the outward reported by the United States); for example, with Luxembourg there is a difference of -US\$233 billion, and with Mexico there is a difference of -US $\$ 130$ billion, representing respectively 24 and 13 percent of the total difference in absolute terms.

For the United Kingdom, the difference has opposite sign that in the previous cases, meaning that reported outward data is much lower that the derived outward data. Main difference is with Luxembourg (-US\$347 billion), representing 52 percent of the total asymmetry, followed by the Netherlands and the United States, with differences of -US $\$ 189$ and -US\$130 billion, representing respectively 28 and 20 percent of the total difference. These findings are like those for the inward. There are also some differences acting in the opposite direction (meaning that outward reported by United Kingdom is higher than outward derived); this is mostly due to counterparts that do not report inward data (mainly Jersey, Cayman Islands, and British Virgin Islands, with differences representing respectively 4,3 , and 2 percent of the total difference in absolute terms) but also to countries that report mirror data with lower amounts (for example Belgium, with a difference representing 3 percent of the total difference in absolute terms).

Mirror data are useful to for cross checking purposes; however, it should be used with caution, as some counterpart economies may not provide data. The analysis should be done beyond the comparison between reported and derived data to better understand and explain asymmetries; asymmetries at bilateral level should be analyzed.

\section{CDIS RESUlts by COMPILING ECONOMY}

The next step in the top down approach to analyze asymmetries is comparing data bilaterally for individual economies and their individual counterparts. This section shows bilateral comparisons for 20 smallest and 20 largest asymmetries.

\section{A. Smallest Bilateral Asymmetries}

Table 3 presents inward data reported by 23 economies with differences not exceeding three percent of the total when compared with outward data reported by counterpart economies. These small differences reflect that: (i) economies undertake bilateral reconciliations or comparisons with their main counterpart economies to improve the accuracy of their estimates; (ii) economies use the mirror data provided by their counterpart economies to adjust their own estimates; (iii) data sources used by the two economies involved to collect direct investment positions are accurate and the coverage is adequate; and/or (iv) compilers follow the same methodological standards. 
Table 3. Twenty Smallest Bilateral Asymmetries as of end-2015

\begin{tabular}{|c|c|c|c|c|c|}
\hline $\begin{array}{r}\text { Reporting } \\
\text { Economy }\end{array}$ & $\begin{array}{l}\text { Counterpart } \\
\text { Economy }\end{array}$ & $\begin{array}{c}\text { Inward reported } \\
\text { by the reporting } \\
\text { economy }\end{array}$ & $\begin{array}{c}\text { Outward reported } \\
\text { by the counterpart } \\
\text { economy }\end{array}$ & $\begin{array}{c}\text { Difference } \\
\text { Absolute } \\
\text { value }\end{array}$ & $\%$ \\
\hline United States & Japan & 411,201 & 413,194 & 1,993 & 0 \\
\hline United States & Germany & 255,471 & 254,286 & 1,185 & 0 \\
\hline Belgium & Luxembourg & 160,004 & 155,240 & 4,763 & 3 \\
\hline South Africa & Netherlands & 37,476 & 36,626 & 850 & 2 \\
\hline Spain & Italy & 37,452 & 37,722 & 270 & 1 \\
\hline Poland & Germany & 29,889 & 30,196 & 307 & 1 \\
\hline Norway & Sweden & 26,274 & 26,335 & 60 & 0 \\
\hline Canada & United Kingdom & 24,759 & 25,536 & 777 & 3 \\
\hline Austria & Russian Federation & 20,976 & 21,054 & 79 & 0 \\
\hline Turkey & Netherlands & 18,854 & 18,798 & 56 & 0 \\
\hline Canada & Japan & 15,896 & 16,062 & 166 & 1 \\
\hline Singapore & Germany & 14,559 & 14,188 & 371 & 3 \\
\hline Australia & Germany & 12,592 & 12,206 & 386 & 3 \\
\hline United States & China, P.R.: Hong Kong & 11,102 & 11,036 & 66 & 1 \\
\hline Spain & Portugal & 10,552 & 10,374 & 179 & 2 \\
\hline Russian Federation & Switzerland & 8,552 & 8,543 & 9 & 0 \\
\hline Slovak Republic & Netherlands & 8,536 & 8,487 & 50 & 1 \\
\hline Turkey & Spain & 7,088 & 7,032 & 56 & 1 \\
\hline Turkey & Russian Federation & 6,040 & 6,013 & 27 & 0 \\
\hline Canada & Australia & 6,025 & 6,213 & 188 & 3 \\
\hline
\end{tabular}

Source IMF's CDIS, 2016 release

\section{B. Largest Bilateral Asymmetries}

The CDIS exercise has proven to be of utmost importance in identifying and creating awareness of large asymmetries between data provided by some economies versus data provided by their counterpart economies.

Table 4 shows the top twenty bilateral asymmetries as of end-2015. The table comprises eleven economies of which seven (Canada, China, Hong Kong, Luxembourg, Netherlands, Switzerland, the United Kingdom, and the United States) are also included in Table 3 (smallest bilateral asymmetries). Section V discusses the main reasons for asymmetries, based on numerous communications with CDIS reporting economies, existing CDIS metadata, and a survey conducted by STA in May 2016, which had a large response rate. 
Table 4. Twenty Largest Bilateral Asymmetries as of end-2015

(US Dollars, millions)

\begin{tabular}{|c|c|c|c|c|c|}
\hline Reporting Economy & $\begin{array}{l}\text { Counterpart } \\
\text { Economy }\end{array}$ & $\begin{array}{c}\text { Inward reported } \\
\text { by the reporting } \\
\text { economy }\end{array}$ & $\begin{array}{l}\text { Outward } \\
\text { reported by the } \\
\text { counterpart } \\
\text { economy }\end{array}$ & $\begin{array}{c}\text { Difference } \\
\text { Absolute } \\
\text { value }\end{array}$ & $\%$ \\
\hline United States & Luxembourg & 328,400 & $1,011,038$ & 682,638 & 208 \\
\hline China, P.R.: Mainland & China, P.R.: Hong Kong & $1,238,823$ & 607,960 & 630,863 & 51 \\
\hline United Kingdom & Luxembourg & 104,733 & 698,015 & 593,281 & 566 \\
\hline Luxembourg & United Kingdom & 498,010 & 150,782 & 347,228 & 70 \\
\hline United Kingdom & Netherlands & 231,565 & 494,631 & 263,067 & 114 \\
\hline Luxembourg & United States & 736,318 & 502,998 & 233,320 & 32 \\
\hline United States & Netherlands & 282,525 & 514,344 & 231,819 & 82 \\
\hline Netherlands & United Kingdom & 364,574 & 175,967 & 188,607 & 52 \\
\hline Luxembourg & Netherlands & 494,221 & 682,642 & 188,421 & 38 \\
\hline Netherlands & Luxembourg & 721,968 & 534,763 & 187,205 & 26 \\
\hline United Kingdom & United States & 432,987 & 593,028 & 160,041 & 37 \\
\hline Luxembourg & Canada & 177,920 & 36,252 & 141,668 & 80 \\
\hline Netherlands & Switzerland & 256,832 & 122,829 & 134,003 & 52 \\
\hline United States & United Kingdom & 483,841 & 353,390 & 130,451 & 27 \\
\hline Mexico & United States & 222,476 & 92,812 & 129,664 & 58 \\
\hline Ireland & Luxembourg & 151,641 & 264,261 & 112,620 & 74 \\
\hline Switzerland & Luxembourg & 207,398 & 316,342 & 108,944 & 53 \\
\hline Switzerland & Netherlands & 183,523 & 289,527 & 106,005 & 58 \\
\hline United States & Ireland & 13,455 & 109,186 & 95,731 & 711 \\
\hline Brazil & Netherlands & 110,210 & 199,106 & 88,896 & 81 \\
\hline
\end{tabular}

Source IMF's CDIS, 2016 release

\section{Main Reasons for Bilateral Asymmetries}

The root for asymmetries is often at national level due to inadequate or partial data sources, lack of information, and noncompliance with recommended guidelines. Bilateral asymmetries are mainly due to limitations faced by economies in their compilation process or to the use of methodologies deviating from the standards. Nevertheless, in some cases (mainly related to the case of fellows) asymmetries may arise even when economies follow current international methodological standards.

This section focuses and provides example of seven main reasons for CDIS bilateral asymmetries: (a) way of recording positions between fellow enterprises when the ultimate controlling parent (UCP) is nonresident; (b) different coverage and lack or partial coverage; (c) different geographic allocation arising from the use of the immediate vs ultimate counterpart economy; (d) unallocated or confidential data; (e) methodological differences in the valuation for listed and unlisted equity and debt instrument or the identification and exclusion of debt between affiliated financial corporations; (f) use of different data sources and estimation techniques; and (g) criteria for identifying entities in a direct investment relationship. 


\section{A. Asymmetries Arising from the Recording of Positions Between Fellow Enterprises when the Ultimate Controlling Parent (UCP) is Nonresident}

CDIS bilateral asymmetries may result from the treatment of direct investment positions between fellow enterprises (see Annex II for definitions). These asymmetries arise when comparing outward direct investment reported by the economy of one fellow enterprise with inward direct investment positions reported by the economy of the second fellow enterprise, when the UCP is nonresident for both economies. However, these asymmetries are not real because they can be eliminated when comparing the total direct investment positions (outward minus inward) between the two economies hosting the fellow enterprises.

This asymmetry only arises when the UCP of the two fellow enterprises is resident in a third economy, different than the economies of the two fellow enterprises. In this case, the application of the extended directional principle, to record positions between fellows, gives rise to inward positions in one economy and negative inward positions in its counterpart economy (rather than the corresponding outward positions). This circumstance causes asymmetries of the same size and opposite sign when comparing both economies' inward and outward data.

\section{Example}

Fellow enterprise $\mathrm{A}$ is resident in economy $\mathrm{A}$ and its fellow enterprise $\mathrm{B}$ is resident in economy $\mathrm{B}$, and both economies apply the extended directional principle to record data on fellows:

If the $\mathrm{UCP}$ is resident in a third economy (e.g., economy $\mathrm{C}$ ) different than the economies of the two fellow enterprises:

- Economy A will record all assets and liabilities between the fellows A and B in inward (because the UCP is nonresident) and

- Economy B will record all assets and liabilities between the fellows $A$ and $B$ in inward (because the UCP is nonresident), and with opposite sign.

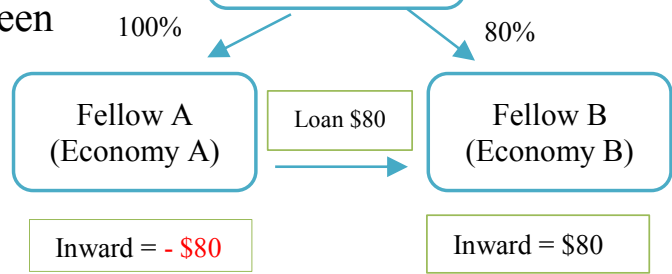

In this case, there would be a bilateral asymmetry between inward data reported by one economy and outward data reported by the counterpart economy, because both economies will record all assets and liabilities between fellow enterprises under inward because the UCP is nonresident for both fellows. 
To eliminate these asymmetries caused by the recording of positions between fellow enterprises when the UCP is nonresident for both fellow enterprises, total net direct investment positions (outward minus inward) reported by one economy should be compared with total net direct investment positions (inward minus outward) reported by its counterpart economy:

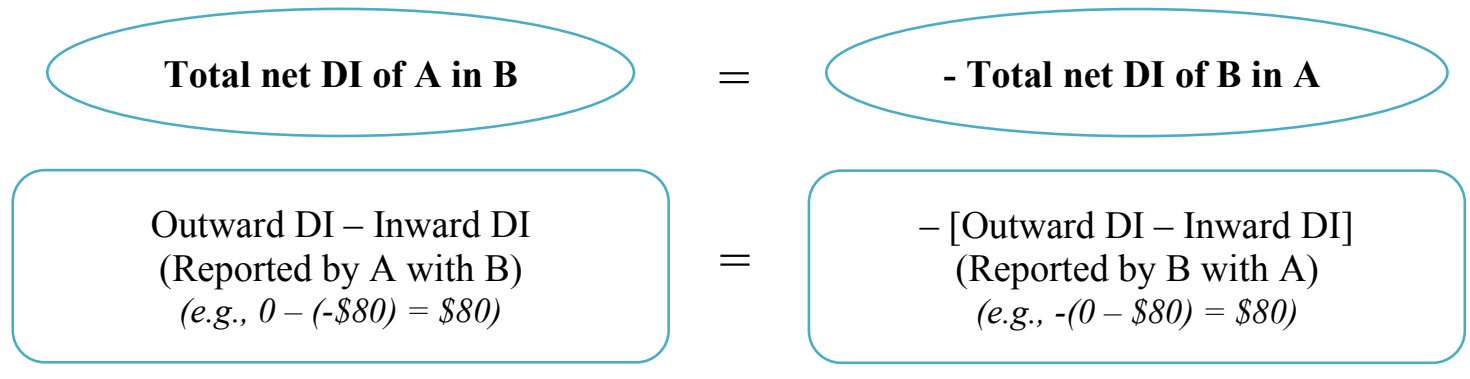

Some of the largest bilateral asymmetries included in Table $\mathbf{4}$ are reduced when total net direct investment positions are compared and therefore, the effect of this asymmetry is eliminated.

Table 5-A. Bilateral Asymmetries from Total Direct Investment as of end-2015 (US Dollars, millions)

\begin{tabular}{|c|c|c|c|c|c|c|c|c|}
\hline $\begin{array}{l}\text { Reporting } \\
\text { Economy }\end{array}$ & $\begin{array}{c}\text { Counterpart } \\
\text { economy }\end{array}$ & $\begin{array}{c}\text { Outward } \\
\text { reported by } \\
\text { the } \\
\text { reporting } \\
\text { economy }\end{array}$ & $\begin{array}{c}\text { Inward } \\
\text { reported by } \\
\text { the } \\
\text { counterpart } \\
\text { economy }\end{array}$ & $\begin{array}{c}\text { Diff. }= \\
\text { Outward } \\
\text { - Inward } \\
\text { (A) }\end{array}$ & $\begin{array}{l}\text { Inward } \\
\text { reported } \\
\text { by the } \\
\text { reporting } \\
\text { economy }\end{array}$ & $\begin{array}{l}\text { Outward } \\
\text { reported by } \\
\text { the } \\
\text { counterpart } \\
\text { economy }\end{array}$ & $\begin{array}{c}\text { Diff. }= \\
\text { Outward } \\
\text { - Inward } \\
\text { (B) }\end{array}$ & $\begin{array}{c}\text { Total } \\
\text { Diff. } \\
\text { (A) + } \\
\text { (B) }\end{array}$ \\
\hline Luxembourg & Netherlands & 534,763 & 721,968 & $-187,205$ & 494,221 & 682,642 & 188,421 & 1,217 \\
\hline Brazil & Netherlands & $-21,417$ & 63,964 & $-85,381$ & 110,210 & 199,106 & 88,896 & 3,515 \\
\hline
\end{tabular}

Table 5-A includes two examples on large bilateral asymmetries that are reduced when netting the differences applying the formula described above. The asymmetry between outward data reported by Luxemburg in Netherlands and the corresponding inward reported by the Netherlands is very large ( $\$ 187$ billion). A similar asymmetry is obtained when comparing outward reported by the Netherlands in Luxemburg with the corresponding inward reported by Luxemburg ( $\$ 188$ billion). However, when comparing total net direct investment reported by these two economies, the asymmetry is reduced to $\$ 1.2$ billion. The same applies to the asymmetries between Brazil and the Netherlands which show a decrease from around $\$ 85$ billion to $\$ 3.5$ billion. 
The same information could be presented as follows:

Table 5-B. Bilateral Asymmetries in Total Direct Investment as of end-2015

(US Dollars, millions)

\begin{tabular}{|c|c|c|c|c|c|c|c|c|}
\hline \multirow{2}{*}{$\begin{array}{l}\text { Reporting } \\
\text { Economy }\end{array}$} & \multirow{2}{*}{$\begin{array}{l}\text { Counterpart } \\
\text { economy }\end{array}$} & \multicolumn{3}{|c|}{ Reporting Economy } & \multicolumn{3}{|c|}{ Counterpart economy } & \multirow[b]{2}{*}{ Diff } \\
\hline & & Outward & Inward & $\begin{array}{c}\text { Total DI } \\
\text { (net) }\end{array}$ & Outward & Inward & $\begin{array}{c}\text { Total DI } \\
\text { (net) }\end{array}$ & \\
\hline Luxembourg & Netherlands & 534,763 & 494,221 & 40,542 & 682,642 & 721,968 & $-39,326$ & 1,217 \\
\hline Brazil & Netherlands & $-21,417$ & 110,210 & $-131,627$ & 199,106 & 63,964 & 135,142 & 3,515 \\
\hline
\end{tabular}

In order to compare bilateral data using the total direct investment positions, countries should report both inward and outward positions, but some CDIS reporting economies do not provide outward data.

Annex 3 includes additional examples and analyzes asymmetries that could arise in one of the components of direct investment (direct investment between fellow enterprises), when one economy collects consolidated data from local enterprise groups (LEGs).

\section{B. Different Coverage, Lack or Partial Coverage}

Different coverage, lack of coverage, or partial coverage for special purpose entities (SPEs), fellow enterprises, nonfinancial private sector, and real estate may create large asymmetries. The capacity to compile data from these institutional units greatly varies from one economy to another, including the systems used to collect them which could imply different coverage.

\section{Special Purpose Entities (SPEs)}

Direct investment positions involving SPEs should be included in the CDIS (see Annex IV). The different coverage levels for SPEs by CDIS participants have significant impact on CDIS asymmetries. The CDIS metadata questionnaire reveals that SPEs are not evenly covered by all participating economies. Some CDIS reporters fully cover SPEs (such as Netherlands), while others only collect partial data (such as Luxembourg and Mauritius), and for other economies SPEs are not covered (such as Seychelles and Curacao). For some countries, SPEs phenomenon is negligible or not relevant (e.g., Italy and South Africa).

In addition, some economies include SPEs' data in their CDIS, but are not able to allocate SPEs investments to any specific country or consider these investments confidential. In these cases, data related to SPEs are reported under "Not Specified (including Confidential)", with no counterpart economy detail. This could give rise to significant asymmetries at bilateral economy level, but would have no impact at aggregate level. 


\section{Resident SPEs in Direct Investment Data}

Asymmetries resulting from different coverage levels for SPEs can vary by economy, depending on the significance SPEs have over their total direct investment. Currently, the CDIS does not separately identify data for SPEs; however, OECD requests direct investment data to be reported separately for resident SPEs.

Table 6 shows 2015 data extracted from OECD database with the identification of resident SPEs data for inward and outward direct investment positions. For Luxembourg, the share of direct investment positions through SPEs is nearly the full amount of direct investment positions (over 90 percent) for both inward and outward. For the Netherlands, the share of SPEs is 82 percent in inward and 76 percent in outward. For Hungary, the share of SPEs is respectively 57 and 77 percent. For other economies, the SPEs contribution is nil (for example for United States, Italy, and Japan).

Table 6. Total Direct Investment Positions with Split by Resident SPEs - OECD Data

\begin{tabular}{|c|c|c|c|c|c|c|}
\hline \multirow{2}{*}{$\begin{array}{c}\text { US Dollar (millions) } \\
\text { Type of entity }\end{array}$} & \multicolumn{3}{|c|}{ Inward } & \multicolumn{3}{|c|}{ Outward } \\
\hline & All resident units & Resident SPEs & $\%$ & All resident units & Resident SPEs & $\%$ \\
\hline \multicolumn{7}{|l|}{ Reporting country } \\
\hline Austria & 262,641 & 91,430 & $35 \%$ & 311,507 & 101,837 & $33 \%$ \\
\hline Belgium & 455,379 & 28,165 & $6 \%$ & 446,250 & 13,207 & $3 \%$ \\
\hline Chile & 221,986 & 1,252 & $1 \%$ & 101,791 & 2,331 & $2 \%$ \\
\hline Denmark & 113,888 & 13,759 & $12 \%$ & 183,201 & 12,937 & $7 \%$ \\
\hline Hungary & 197,551 & 113,090 & $57 \%$ & 151,893 & 117,033 & $77 \%$ \\
\hline Iceland & 11,293 & 3,442 & $30 \%$ & 11,079 & 3,442 & $31 \%$ \\
\hline Korea & 169,659 & 736 & $0 \%$ & 276,153 & 53 & $0 \%$ \\
\hline Luxembourg & $3,271,864$ & $3,044,784$ & $93 \%$ & $3,829,324$ & $3,622,873$ & $95 \%$ \\
\hline Netherlands & $3,956,821$ & $3,239,357$ & $82 \%$ & $4,714,195$ & $3,592,423$ & $76 \%$ \\
\hline Norway & 143,422 & 1,771 & $1 \%$ & 165,330 & 981 & $1 \%$ \\
\hline Poland & 185,177 & 1,308 & $1 \%$ & 23,589 & 1,308 & $6 \%$ \\
\hline Portugal & 118,986 & 13,580 & $11 \%$ & 56,733 & 8,961 & $16 \%$ \\
\hline Spain & 547,265 & 38,919 & $7 \%$ & 490,322 & 29,297 & $6 \%$ \\
\hline Sweden & 302,525 & 21,933 & $7 \%$ & 374,280 & 16,892 & $5 \%$ \\
\hline Switzerland & 839,827 & 122,956 & $15 \%$ & $1,129,768$ & 104,591 & $9 \%$ \\
\hline
\end{tabular}

Data extracted on 03 Oct 2017 16:17 UTC (GMT) from OECD.Stat

(Dataset: FDI positions, main aggregates BMD4)

Note zero values (resident SPEs not present or not significant) were excluded.

\section{Nonresident SPEs in Direct Investment Data}

While some countries are main destinations of SPEs (such as Netherlands, which deals mainly with pass-through funds), others are characterized by outward investment in SPEs. This is the case of Russia; it is not perceived as a transit economy for international crossborder financial flows, and there are no SPEs in Russia, however, Russian enterprises traditionally use SPEs registered abroad in the conduct of their economic activities for 
buyback operations, holding companies, and conduit companies. Most popular jurisdictions for establishing holding companies for investing in Russia include the Netherlands as well as Bahamas, Bermuda, and British Virgin Islands. Russian companies also choose off-shore countries for registration of such SPEs aimed at optimization of tax payments (IMF, BOPCOM 16/21).

\section{Lack of Participation in CDIS of Economies Hosting SPEs}

Many economies hosting SPEs do not participate in the CDIS. As explained in Annex I, derived data based on mirror information are a very useful source of information for economies that do not compile direct investment data, and can give insights of their total inward and outward direct investment positions with counterpart economy breakdown.

The table below shows the top 15 economies that did not report 2015 CDIS data, ranked based on their derived inward and outward data as reported by their counterpart CDIS reporting economies. For 2015, inward and outward derived data for non-reporters represent 10 and 12 percent of the total reported inward and outward positions respectively. There are many economies that do not report CDIS; however, investments are concentrated in few economies. The top 15 non-reporters represent 89 and 94 percent of the total non-reported data for inward and outward respectively. An interesting finding is that most significant non CDIS reporters are economies that host SPEs, with British Virgin Islands, Bermuda, and Cayman Islands heading the ranking.

There are challenges in data collection for SPEs, including lack of statistical capacity, unavailability of information due to the confidential nature of these entities, and unwillingness to invest in compilation due to their limited economic impact on the domestic economies (IMF, BOPCOM 16/18). 
Table 7. Top 15 Economies that Did Not Report 2015 Inward/Outward CDIS (ranking based on derived data)

(US Dollars, millions)

\begin{tabular}{|c|c|c|c|c|c|c|}
\hline \multirow[b]{2}{*}{2015} & \multicolumn{3}{|c|}{ Inward Derived } & \multicolumn{3}{|c|}{ Outward Derived } \\
\hline & Total & $\begin{array}{c}\text { Equity } \\
\text { (Net) }\end{array}$ & $\begin{array}{l}\text { Debt } \\
\text { (Net) }\end{array}$ & Total & $\begin{array}{c}\text { Equity } \\
\text { (Net) }\end{array}$ & $\begin{array}{l}\text { Debt } \\
\text { (Net) }\end{array}$ \\
\hline Virgin Islands, British & 642,764 & 492,090 & 125,419 & $1,134,319$ & 961,062 & 85,922 \\
\hline Bermuda & 632,105 & 607,018 & $-32,119$ & 710,520 & 510,981 & 93,013 \\
\hline Cayman Islands & 554,091 & 494,080 & 25,431 & 568,772 & 365,098 & 142,119 \\
\hline Gibraltar & 121,606 & 76,451 & $-8,475$ & 189,199 & 171,050 & 7,488 \\
\hline Puerto Rico & 109,951 & 91,103 & 18,848 & 270 & 202 & 47 \\
\hline Bahamas, The & 82,774 & 26,730 & 2,958 & 98,304 & 64,051 & 13,253 \\
\hline Barbados & 73,772 & 17,896 & $-1,926$ & 16,062 & 9,518 & 3,372 \\
\hline United Arab Emirates & 73,420 & 69,179 & 3,207 & 88,372 & 35,631 & 31,583 \\
\hline Argentina & 67,945 & 61,978 & 4,795 & 12,992 & 13,087 & -781 \\
\hline Jersey & 66,162 & 110,264 & $-44,639$ & 249,294 & 207,614 & 25,497 \\
\hline Egypt & 61,602 & 39,895 & 6,076 & 416 & 594 & -125 \\
\hline Saudi Arabia & 47,933 & 25,325 & 7,150 & 14,858 & 13,477 & 770 \\
\hline Taiwan Province of China & 45,477 & 25,272 & 898 & 70,049 & 53,656 & 2,616 \\
\hline Colombia & 37,586 & 36,544 & $-1,603$ & 18,331 & 17,974 & 436 \\
\hline Peru & 35,374 & 26,401 & 1,440 & 1,439 & 1,884 & $-1,052$ \\
\hline Total Top 15 non-reporters & $2,652,560$ & $2,200,224$ & 107,459 & $3,173,198$ & $2,425,878$ & 404,157 \\
\hline$\%$ Top 15/total non-reporters & $89 \%$ & $90 \%$ & $76 \%$ & $94 \%$ & $94 \%$ & $91 \%$ \\
\hline Total non-reporters & $2,968,281$ & $2,448,574$ & 140,525 & $3,378,389$ & $2,574,071$ & 443,130 \\
\hline$\%$ Non-reporters/total reported & $10 \%$ & $11 \%$ & $4 \%$ & $12 \%$ & $10 \%$ & $20 \%$ \\
\hline Total World (as reported) & $28,405,605$ & $23,075,491$ & $3,750,588$ & $28,244,188$ & $25,165,725$ & $2,200,781$ \\
\hline
\end{tabular}

Source IMF's CDIS, 2016 release

\section{Fellow Enterprises}

Equity and debt instrument positions between fellow enterprises are to be classified as direct investment and therefore included in the CDIS data. ${ }^{4}$ However, some economies do not cover these positions under direct investment, mostly because they are not able to identify them; they would instead classify these positions under portfolio or other investment, causing asymmetries with counterpart economies. Several economies are updating their surveys to collect data on investment with fellow enterprises, in their efforts to transitioning to the sixth edition of the Balance of Payments and International Investment Position Manual (BPM6).

About half of the 107 economies reporting 2015 inward data separately identify investment between fellow enterprises. For the outward CDIS, 32 out of 73 economies separately identify investments for fellows. The fact that economies do not separately identify investments with fellows does not necessarily mean that they do not cover them in the CDIS. Countries that collect direct investment data using the local enterprise group as reporting unit cannot separately identify data between fellow enterprises (e.g., the United States). The

\footnotetext{
${ }^{4}$ Definition and compilation are described in Annex II.
} 
importance of investments between fellows varies by economy, and therefore its potential impact on asymmetries. The importance could be measured based on separate fellow enterprise data reported in CDIS. Inward positions with fellow enterprises represent 40 percent of total inward direct investment in Belgium while it only represents 0.6 percent in Switzerland. Annex V shows the positions between fellow enterprises relative to the total inward and outward investment for CDIS participants that separately identify fellows.

\section{Nonfinancial Private Corporations}

Low participation in the direct investment surveys of the nonfinancial private corporations, which in many economies comprise the bulk of target respondents, is a key challenge for compilers. Gaps in the coverage of investments for the nonfinancial sector can result in bilateral asymmetries if the level of coverage of counterpart economies is different.

The collection of direct investment data from the nonfinancial private sector could be based on a sample or a census. Based on the responses to the CDIS metadata questionnaire, most of the economies collect data from a sample of the target population for the nonfinancial corporations with direct investment positions. Data are collected from a census of enterprises by 33 percent of the reporting economies for inward and 20 percent for outward. The response rate to the surveys could also vary and produce bilateral asymmetries.

The absence of a legal mandate to collect data from nonfinancial corporations for statistical purposes continues to be the main reason for low response rate to surveys (see Philippines' Experience (BOPCOM 16/27)). Low response rate may result because survey participation is voluntary. However, legal mandate itself may not suffice to significantly improve response rate and should be combined with other measures. Online survey questionnaires that are user friendly, consultative meetings with industry associations, and company visits to nonresponding corporations are effective in encouraging reporting.

\section{Real Estate}

Investments in real estate by nonresidents could be significant for some recipient/investor countries, however, they may not be covered. This can cause asymmetries with counterpart investing economies that do cover such investments. According to the responses to the CDIS metadata, around 40 percent of CDIS reporting economies include data on real estate in their direct investment. The level of coverage could vary. 
Most of the positions on real estate involve the household sector which is the most difficult to cover because household surveys are costly and cannot be conducted with the required periodicity. Compilers need to collect these data mainly through public registers. In some countries, real estate data are covered, but the counterpart economy allocation may not be accurate or it is not provided (e.g., Austria). In Russia, direct

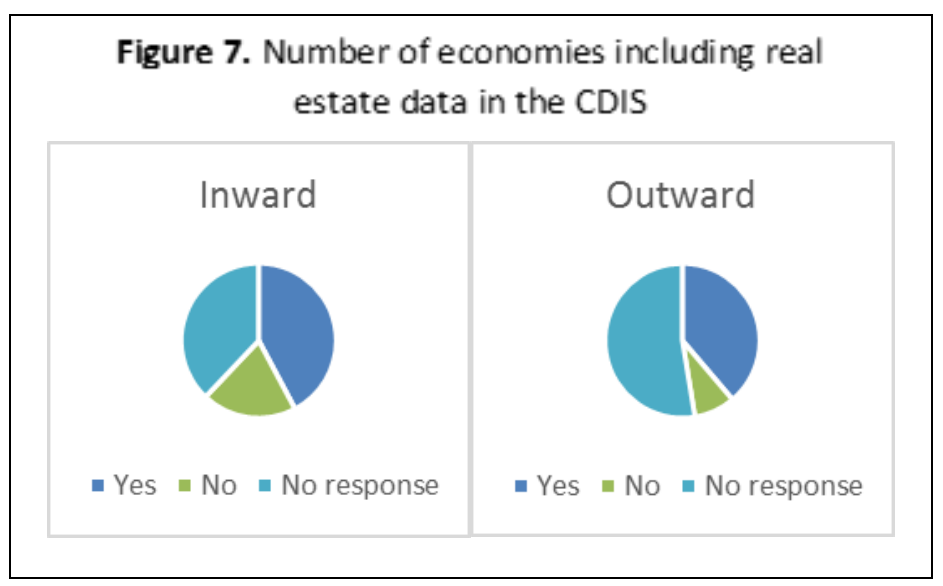

Source IMF's CDIS, 2016 release investments of individuals in real estate are included in CDIS. The main data source is banks' reports on personal transfers for real estate purchases (international transaction reporting system). However, counterpart economy breakdown is not always correct for this kind of data, as often the receiving country is not the destination, but a place of transit. For example, the main destination country for real estate purchase transfers is Switzerland from where the funds are further transferred to the countries in which the real estate is ultimately purchased (Central Bank of the Russian Federation BOPCOM 15/10.b)

\section{Different Geographic Allocation: Immediate vs. Ultimate Investing Economy}

CDIS guidelines establish that direct investment data be reported by immediate (first) counterpart economy for both inward and outward direct investment positions. However, some countries rather allocate inward direct investment positions to the ultimate investing economy (the economy of the ultimate investor in the chain of ownership). It has also been observed that if the first enterprise is a nonresident SPE, few countries determine the counterpart economy looking through the nonresident SPE up to the next enterprise in the ownership chain. In this case, differences in the geographic allocation of direct investment positions between counterpart economies could produce bilateral asymmetries at country level, but not at global level. Inward direct investment positions by ultimate investing economy are also useful for analysis and some economies compile this additional breakdown.

The ultimate investor, for this purpose, is the enterprise that has control over the investment decision to have a direct investment position in the direct investment enterprise. The country in which the ultimate investor is resident is the ultimate investing country for the investment in the direct investment enterprise. It is possible that the ultimate investor is a resident of the same economy as the direct investment enterprise (Paragraphs 610 and 611 of $B D 4)$. 


\section{Unallocated and Confidential Data}

When economies are unable to identify the counterpart country or this information is confidential, data are reported under the CDIS component: "Not specified (including confidential)". The reporting of confidential or unallocated data by counterpart economy does not affect global asymmetries, but prevents from conducting accurate bilateral comparisons and may ultimately affect the analytical value of the data if the weight of the not specified data is relevant.

Figure 8 shows the weights of "Not Specified (including confidential)" over total direct investment along the periods covered by the CDIS. The values are quite steady over the years, except for the increase shown in 2012 for inward and in 2012/2013 in outward positions. At global level, data reported as not allocated or confidential represent around 6 percent for inward and 7 percent for outward and have decreased in the last two years. For some economies, there are relevant values under "Not specified" compared with their total direct investment.

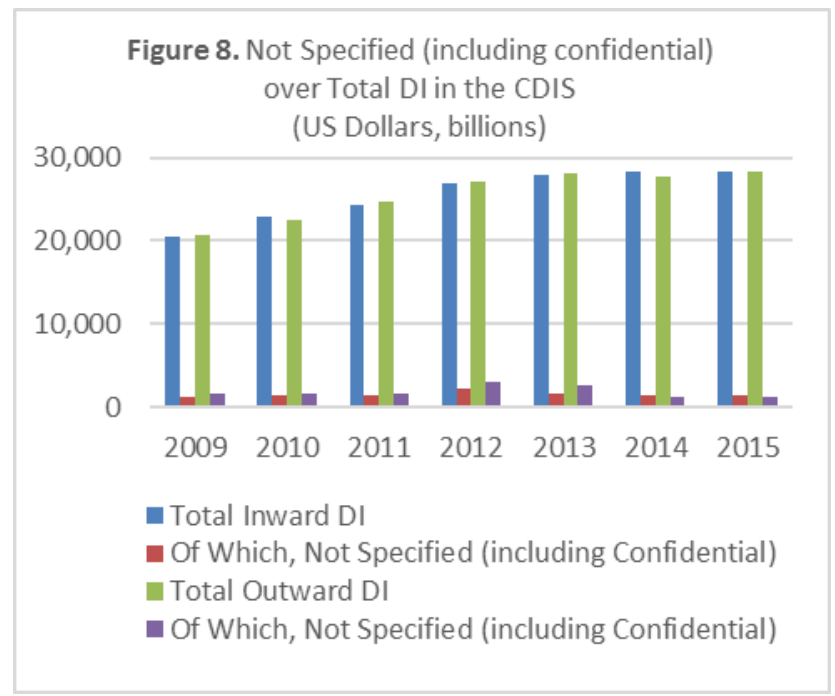

Source IMF's CDIS, 2016 release

Annex VI shows the top economies reporting unallocated or confidential data in percentage to their total inward or outward direct investment positions and representing more than 15 percent. For inward, there are 16 economies with a percentage larger than 15 percent and for outward there are 10 economies. The large amounts of not specified data provided by these economies hamper bilateral comparisons with their counterpart economies. However, it can be concluded that for most other CDIS reporting economies, the amounts reported as not specified are not significant.

When datasets provide more granular information with additional breakdowns and details, there is a risk of increasing the values reported as confidential; this is, the more granular the data, the higher the risk of confidentiality. Confidentiality issues can play a role for specific counterpart economies, investments or statistical units. For example, in some economies SPEs are covered in CDIS, but due to their limited number there are confidentiality restrictions and their data are not allocated to a specific counterpart (reported under "Not specified (including confidential)"). ${ }^{5}$

\footnotetext{
${ }^{5}$ See Austria's CDIS metadata questionnaire, question i-11.
} 


\section{E. Methodological Issues}

\section{Valuation Methods}

As direct investment is mainly concentrated in equity, representing around 80 percent of the total direct investment, the use of different valuation methods, mainly for unlisted equity, could produce large bilateral asymmetries between counterpart countries. The exchange of data and metadata between compilers could help to understand and address some of the main bilateral asymmetries.

\section{Valuation Methods for Direct Investment Equity in the CDIS}

This section analyzes the bilateral asymmetries that could be produced by applying different valuation methods for estimating direct investment positions on equity. International standards set that all financial positions should be valued at market value.

Positions of financial assets and liabilities should, in general, be valued as if they were acquired in market transactions on the balance sheet reporting date (BPM6, paragraph 3.84).

Direct investment equity positions included in the CDIS consist of listed equity, unlisted equity, and other equity. In principle, listed equity positions can be valued at market prices, however, there may be no observable market prices for positions in unlisted or other equity. When actual market values are not available, equity positions, in the CDIS, should be valued at own funds at book value $\left(\mathrm{OFBV}^{6}\right)$ as stated in paragraph 3.12 of the CDIS Guide. The more frequent the revaluation of assets and liabilities, the closer the approximation to market values; data that are not revalued for several years may be a poor reflection of market values.

The CDIS Guide requires that, when there are no observable market prices, information be collected from the books of the direct investment enterprise, as they are more likely to consider the activities of the direct investment enterprise than are the books of the direct investor, and because using this valuation helps to promote comparability and consistency of the information collected between economies. The application of OFBV based on the books of the direct investment enterprise would avoid any bilateral asymmetries arising from valuation. However, compilers may face difficulties in having access to this information to compile outward data because, in this case, they may have no access to the books of the nonresident direct investment enterprise. Also, the assets and liabilities reflected in the books should include revaluations to provide an accurate proxy of market values.

The CDIS metadata reveals that not all countries follow the international valuation standards to compile direct investment equity positions, which may give rise to bilateral asymmetries.

\footnotetext{
${ }^{6}$ Own funds at book value: sum of (a) paid-up capital; (b) all types of reserves identified as equity in the enterprise's balance sheet; (c) cumulated reinvested earnings; and (d) holding gains or losses included in own funds in the accounts, whether as revaluation reserves or profits or losses.
} 
Figure 9 reflects the different valuation methods used by CDIS reporting economies based on their replies to the CDIS metadata questionnaire. It shows that most of the CDIS reporting economies follow the international standards and value listed equity at market value and unlisted equity at OFBV. However, a significant number of economies use OFBV to value listed equity. This deviation of the standards may not cause significant asymmetries when the books of the direct investment enterprise are frequently revaluated and reflect the current market value of the company. On the other hand, it could produce large asymmetries when the values recorded in the books of an enterprise are not revalued for several years and are a poor reflection of market values.

Also, significant asymmetries may arise when economies apply other valuation methods, different than market value or OFBV, such as the historic cost (see Box 1). "Historic cost, in its strict sense, reflects the cost at the time of acquisition, but sometimes it also may reflect occasional revaluations." (BPM6,

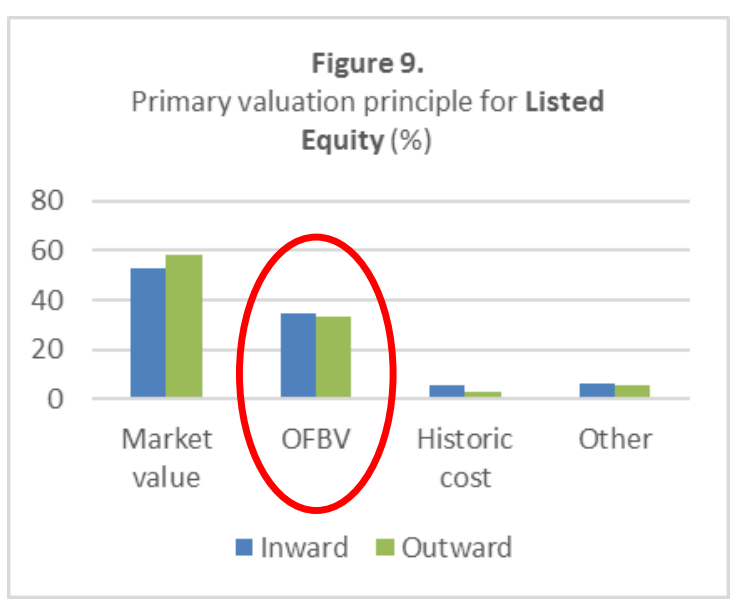
paragraph 3.88 (f)).

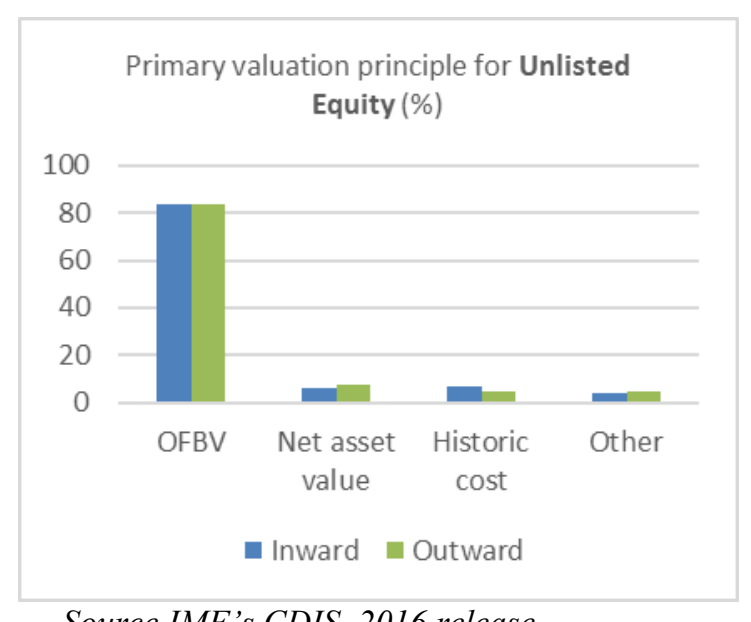

Source IMF's CDIS, 2016 release 


\section{Box 1. A Case of Valuation at Historic Cost: The United States}

In general, equity investment valued at historic cost will produce smaller estimates than valued at market value or OFBV because this valuation method, in principle, does not include revaluations. One of the countries using the historic cost is the United States. All CDIS reporting economies which have provided outward equity positions in the United States (different than null or confidential), when the United States has also provided inward equity positions received from them (different than null or confidential) during the last five years, have been selected. A total of 22 economies meet these criteria.

\section{Table 8. A case of valuation at Historic Cost (US dollars, billions)}

Inwar Equity Positions (Net)

$\begin{array}{lllll}2011 & 2012 & 2013 & 2014 & 2015 \\ 1,550 & 1,728 & 1,847 & 1,933 & 2,087 \\ 2,120 & 2,343 & 2,763 & 2,834 & 3,131 \\ -570 & -615 & -916 & -901 & -1,044\end{array}$

Table 8 shows the aggregated value reported by the United States against the selected 22 economies as inward equity positions and the aggregated value reported by the 22 Unites States' counterpart economies against the United States as outward equity positions. It shows that the asymmetries are always negative, that is, the total amount reported by the US is smaller than the total amount reported by its counterpart economies for the all the period.

However, in some cases, the bilateral asymmetries at individual economy level are positive, in particular, the asymmetries with two of the selected countries (Belgium and the United Kingdom) are positive for the five years covered in this analysis. These positive asymmetries could be explained by the valuation method used by the counterpart economies (Belgium and the United Kingdom use OFBV to value listed equity instead of market value) or by other reasons described in this paper (e.g., coverage or geographical allocation).

Compilers should address these asymmetries and try to estimate the market or fair value of direct investment positions on equity.

\section{Valuation Methods for Debt Instruments in the CDIS}

Debt instruments consist of: (i) debt securities, which should be valued at market prices and (ii) other debt instruments - that is, loans, deposits, insurance, pension, and standardized guarantee schemes, trade credit and advances, and other accounts payable/receivable - which should be valued at nominal value. Nominal value is defined as the amount the debtor owes to the creditor, which comprises the outstanding amount of principal and any accrued interest not yet paid. 
Figure 10 shows the valuation methods used by CDIS reporting economies to value debt instruments as indicated in the CDIS metadata questionnaire. More than 40 percent of the CDIS reporting economies follow the international standards and value debt securities at market value and other debt instruments at nominal value. In principle, the bilateral asymmetries produced on direct investment debt instruments due to the application of different valuation methods by counterpart economies are not expected to be relevant, as market value is not likely to significantly differ from nominal value.

As indicated in Section II, the total amounts reported under inward debt instruments are usually larger the total amounts reported under outward debt instruments at the global level. This behavior is also observed at individual country level. In 2015, 80 percent of the values reported under inward debt instrument positions by individual economies are larger than the corresponding values reported under outward debt instruments positions by their

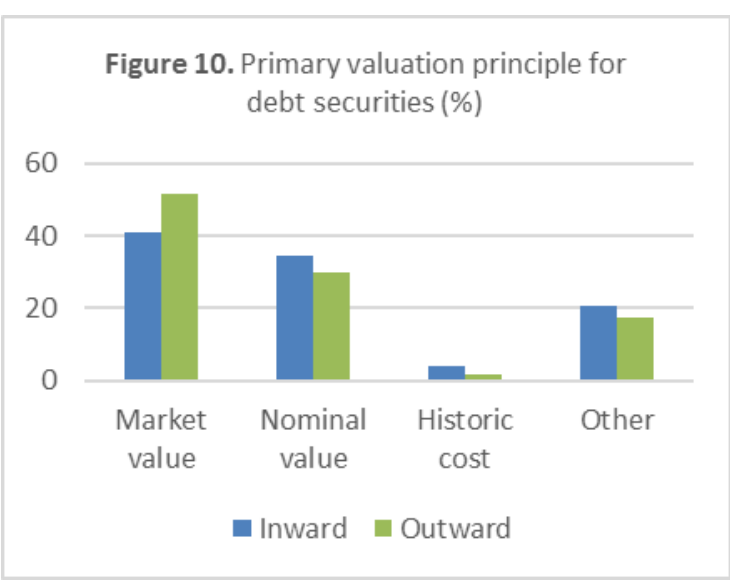

Primary valuation principle for other debt instruments (\%)

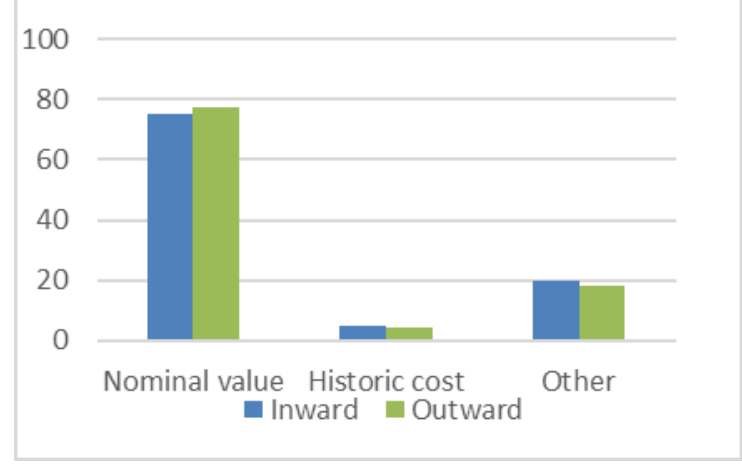

Source IMF's CDIS, 2016 release counterpart economies.

These positive asymmetries could be produced by overestimated inward debt data and /or by underestimated outward debt data mainly due to different data coverage, and to a less extent to the valuation method applied. Compilers usually have access to more accurate data to compile inward direct investment (that is, direct investment in the reporting economy), than to compile direct investment outward (that is, direct investment abroad). Other compilation issues may take into play; for example, debt instrument liabilities (including in the form of intercompany debt) are regularly more closely monitored in the context of external debt than debt instruments assets. In addition, the methods to compile intercompany debt may focus on initial debt disbursements, but may not properly track any debt repayments to the direct investors, or the debt repayments are accounted for through other means or registered in other items (repatriating benefits, under invoicing, etc.). Therefore, in principle, outward debt instruments tend to be underestimated. 


\section{Debt Between Affiliated Financial Corporations}

Debt between selected affiliated financial corporations (deposit-taking corporations, investment funds, and other financial intermediaries except insurance corporations and pension funds) should be excluded from direct investment, because it is not considered to be so strongly connected to the direct investment relationship. This is, when both the resident and the nonresident affiliated enterprises are selected financial corporations, their intercompany debt is excluded from direct investment and included instead in portfolio or other investments, as appropriate. For some economies, data sources may lack of sufficient detail to identify these debt positions between selected affiliated financial corporations, specially to identify the institutional sector of the nonresident enterprise. These positions would therefore not be excluded from direct investment, leading to asymmetries when counterpart economies follow the recommendation and exclude them.

The CDIS metadata shows that most CDIS reporters exclude this debt from direct investment; therefore, in principle, this exclusion should not generate significant bilateral asymmetries.

\section{F. Data Sources and Estimation Techniques}

The use of different data sources to collect direct investment positions, could also give rise to bilateral asymmetries between economies. Compilers collect direct investment positions from diverse and complementary data sources that are combined trying to avoid duplications or omissions. $^{7}$

The main data sources used to collect direct investment positions are enterprise surveys and the financial statements of the companies; they are the most adequate and accurate data sources to compile direct investment positions and should result in consistent data across economies. These data sources could be complemented with additional information. Some countries use complementary data sources to fill data gaps or until the results of the surveys are available.

\footnotetext{
${ }^{7}$ Chapter 9 of the BPM6 CG describes the data sources that can be available to compile international investment position statistics including the data sources that could be used to collect direct investment positions.
} 


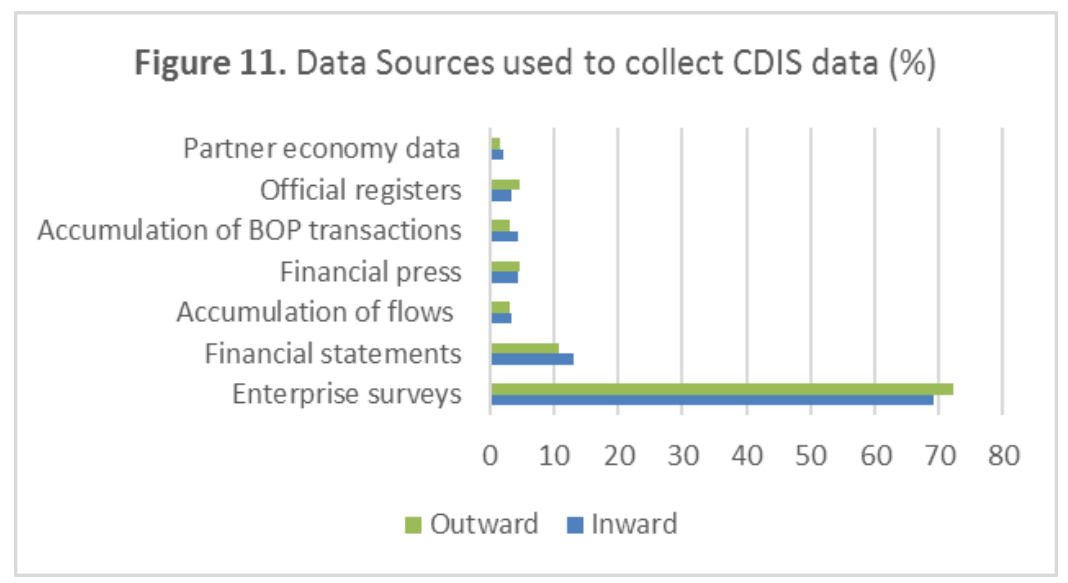

Source IMF's CDIS, 2016 release
Additionally, some countries estimate the data for nonresponding units. The methods used are included in Figure 12 based on the replies to the CDIS metadata questionnaire.

Most of the reporting economies (around 70 percent) apply some estimates to fill the gap of nonresponding companies.

Also, most of the compilers indicate in the metadata questionnaire that the response rate to the surveys is quite high, therefore, in most cases, the estimated amounts are not relevant for the economy.

The use of other data sources different than enterprises surveys or the financial statements of the direct investment enterprises and the use of different methods to estimate data for nonresponding units could produce asymmetries between counterpart economies, but they are not expected to be relevant provided information related to key companies is compiled.

\section{Accumulation of Transactions}

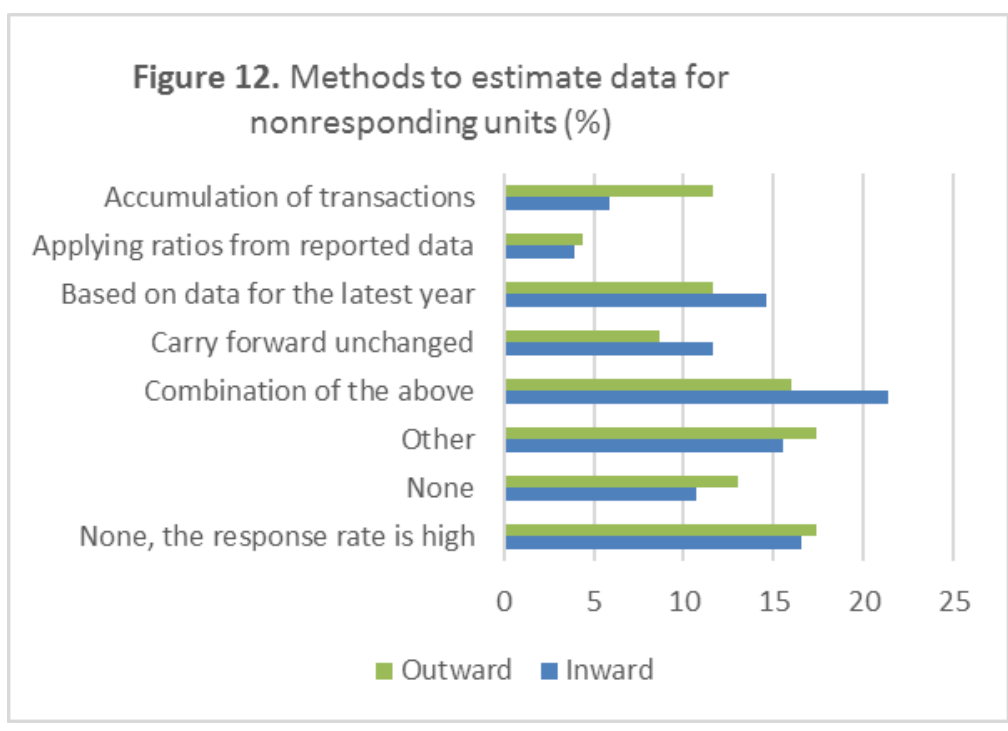

Source IMF's CDIS, 2016 release

As shown in Figure 11, few economies use accumulation of transactions as data source to estimate direct investment positions in the CDIS. Also, some economies use accumulation of transactions to estimate data for nonresponding units.

In principle, compilers may estimate the value of debt instruments positions, different than debt securities, by accumulating transactions with adjustments for exchange rate changes. However, positions on equity and debt securities are more likely to be affected by price changes; therefore, the estimation of positions from balance of payments transactions should take in consideration adjustments for exchange rate and price changes, which may be more difficult to estimate for each negotiable instrument and could lead to bilateral asymmetries. 


\section{G. Criteria for Identifying Entities in a Direct Investment Relationship}

In order to compile direct investment statistics, it is important to identify the resident institutional units that are in a direct investment relationship with nonresidents. Direct investment positions could be misclassified, under portfolio or other investment, if the direct investment relationship has not been identified. These misclassifications could also lead to bilateral and global asymmetries.

Economies should use the framework for direct investment relationships (FDIR) to identify entities in a direct investment relationship. However, some economies follow other criteria and use more simplified methods, such as the direct influence/indirect control, or the participation multiplication method. This results in the classification of direct investment positions under other functional categories_- portfolio investment or other investment. ${ }^{8}$

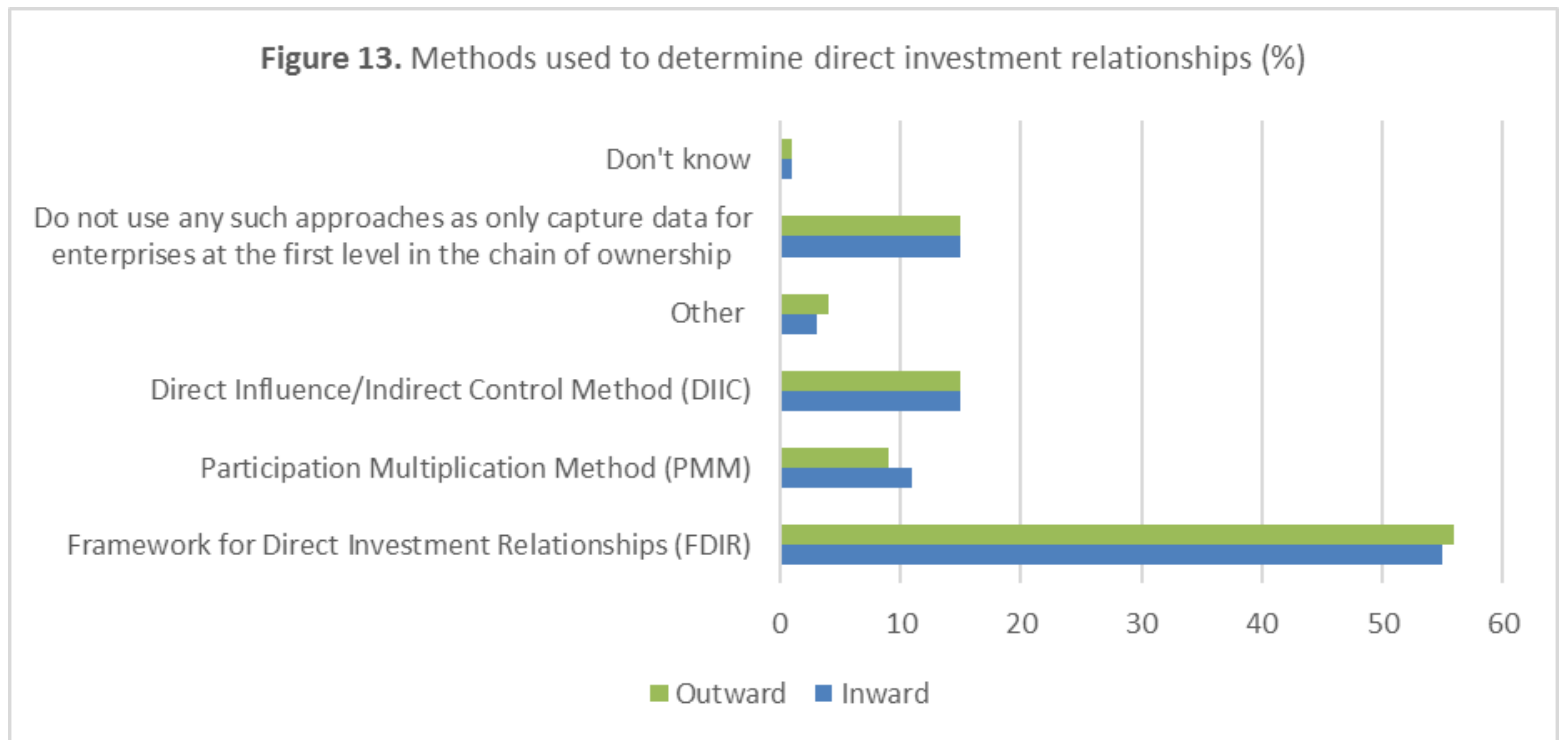

Source IMF's CDIS, 2016 release

More than 50 percent of the CDIS reporters apply the recommended standards and identify direct investment relationships based on the FDIR for both inward and outward positions. Positions between related companies could be misclassified for economies using other method.

\section{AdDressing Bilateral Asymmetries}

The previous section examined the reasons for asymmetries. This section goes one step further proposing ways for addressing them; however, it also recognizes the challenges in the reduction of asymmetries. This section concludes with specific planned actions to reduce asymmetries, including initiatives led by international organizations.

\footnotetext{
${ }^{8}$ For the differences between the three methods, see 2015 CDIS Compilation Guide (paragraphs 2.38 to 2.54).
} 
To reduce bilateral asymmetries, it is essential to comply with international guidelines for recording CDIS data by applying uniform standards in terms of coverage, geographical counterparty allocation, valuation, and criteria for identifying entities in a direct investment relationship. In addition, reducing the reporting of confidential and unallocated data by doing best efforts to allocate investments to specific counterpart economies can also contribute to reduce bilateral asymmetries. Finally, bilateral data exchange at enterprises' level has proved to be an efficient way to identify the reasons for asymmetries and ultimately address them, but may be limited due to confidentiality constraints. Data exchange at more aggregated levels and metadata exchange do not pose confidentiality issues and are useful in understanding asymmetries, but may be less likely to allow addressing and reducing asymmetries. The CDIS provides very valuable information on more aggregated data levels and metadata.

The reduction of asymmetries has always been a challenge for national compilers. Economies involved in bilateral asymmetries exercises conducted by STA have reported specific planned actions to reduce asymmetries. In addition, there are various initiatives led by international organizations, including the IMF, to facilitate bilateral meetings between countries interested in discussing asymmetries in their direct investment statistics. The steps taken to increasing awareness of the asymmetries and understanding the reasons that explain them are, per se, an important achievement, even if it is not feasible to reduce them.

\section{A. Compliance with Recommended Guidelines for Recording CDIS Data}

Compliance with recommended guidelines is a key factor that would reduce asymmetries. Uniform standards in terms of coverage, geographical counterparty allocation, valuation, and criteria for identifying entities in a direct investment relationship are essential.

In terms of coverage, direct investment data should include investments in or from resident SPEs, positions between fellow enterprises, direct investment involving nonfinancial corporations, and real estate. However, in some economies SPEs data may be excluded or only partially covered; fellow enterprises' data may not be identified and therefore classified in data categories other than direct investment; nonfinancial corporations may be poorly covered due to low response rate and lack of the legal mandate to collect data for statistical purposes; and investments in real estate may be out of the scope of the reporting system.

In terms of geographical allocation, the breakdown of positions by counterpart economy should be based on the immediate (first) counterpart economy. However, for inward, some economies report this breakdown based on the ultimate investing economy - that is, the economy in which the ultimate investor is resident — or if the first enterprise is a nonresident

SPE, they may determine the counterpart economy looking through the nonresident SPE until the next enterprise in the ownership chain.

In terms of valuation, market value is the recommended basis for the valuation of listed equity and debt securities. Unlisted equity and other equity should be valued using the 
concept of OFBV, as proxy for market value, obtained from the books of the direct investment enterprise to ensure data comparability and provided frequent revaluations of assets and liabilities are considered. Debt instruments other than debt securities are to be valued at nominal value (amount the debtor owes to the creditor, which comprises the outstanding principal amount including any accrued interest not yet paid). Most of the CDIS reporting economies apply these standards, however, some economies do not follow these recommendations mainly due to limitations in their data sources or compilation process.

In addition, debt between selected affiliated financial corporations should be excluded from direct investment, but in some economies data sources may lack of sufficient detail to identify and exclude this debt from direct investment.

In terms of data sources, position (stock) source data should be used based on enterprise surveys or financial statements of the direct investment enterprises. However, in the absence of position source data, few economies estimate positions from balance of payments transactions, or may use this estimation method for certain sectors/reporters for which position data are unavailable. This can result in asymmetries, particularly if data are not adjusted from changes in positions caused by reasons other than balance of payments transactions (price and exchange rate changes and other flows).

In addition, statistical techniques related to the survey frame need to be appropriate, otherwise, they can lead to inaccurate data. Some economies may use sample surveys, may target enterprises or investments above a certain threshold in their surveys, or may have low response rate to surveys. In these cases, estimation techniques could be used for grossing up the sample to the universe of enterprises, accounting for positions below the threshold, and addressing non-response.

In terms of the criteria for identifying entities that are in a direct investment relationship, the FDIR is conceptually the preferred method. Economies should aim to evolve from more simplified methods to the FDIR.

\section{B. Reducing the Reporting of Confidential and Unallocated Data by Counterpart Economy}

Economies should do best efforts to allocate investments to specific counterpart economies and reduce, to the extent possible, the use of confidential/unallocated counterparts when reporting direct investment data. Whereas higher granularity poses confidentiality issues, the rules to determine when data are confidential may need to be revised and applied only when there is potential risk for identifying the reporting enterprise. Likewise, whereas it may not be feasible to allocate the counterpart economy for certain positions or investments, CDIS reporters should do best efforts to estimate the breakdown by specific counterpart economy.

Unallocated data may play a role in economies that participate in the CDIS for the first time, as they may not be able to allocate all positions by counterpart country in a first stage. 
However, as their data collection systems are enhanced and delayed information received, they should revise back past time series and revisit unallocated figures. CDIS reporters should do best efforts to minimize the use of unallocated data by estimating counterpart economy breakdown. Estimations could be based on counterpart allocation of past data if available, transaction data, mirror information, etc.

\section{Data and Metadata Exchange}

Data exchange at bilateral economy level has proved to be an efficient way to identify the reasons for asymmetries. The most efficient way to identify and ultimately address asymmetries is through a detailed data reconciliation, desirably at the enterprises' level. Data exchange at enterprise level can help identifying missing investments/reporters, deviations in valuation, timing differences, etc., but may be limited due to confidentiality constraints. Data exchange at more aggregated levels and metadata exchange are also useful in identifying and understanding the reasons for asymmetries and do not pose confidentiality issues, but may be less likely to allow addressing and reducing asymmetries. The CDIS provides very valuable information on more aggregated data levels and metadata.

\section{Data Exchange}

Enterprise level data are usually available to compilers through data report forms collected for statistical purposes. Some mechanisms are in place to successfully exchange micro level data at enterprise level bilaterally, such as the FDI Network launched under the auspices of Eurostat and the ECB (see Box 2). Some countries that do not participate in such Network also conduct bilateral exchanges of data regularly, especially with their main counterpart economies.

Bilateral exchange of micro data between statisticians is considered a good practice to reduce asymmetries and to identify the reasons behind them, even if it does not allow for the reconciliation of all transactions and positions.

\section{Box 2. The FDI Network}

The transmission and exchange of confidential data in the context of the FDI Network is foreseen exclusively for statistical purposes and in particular for increasing the consistency/quality of the EU/euro area balance of payments statistics. The transmission of confidential data is enabled pursuant to the specific regulations of the European Parliament and of the Council. The exchange of micro level data between direct investment compilers is based on a secure data exchange between countries which are parties to the financial transaction/position. The concerned countries will then try to reconcile their data.

(ECB/Eurostat BOPCOM 14/20)

However, there are limitations to data exchange due to confidentiality constraints. Confidentiality both at microdata level (enterprise) or at higher levels of aggregation (for 
some types of investments or sectors) may hamper analyzing the bilateral asymmetries with counterpart economies. For some economies, the possibility of sharing micro data with third parties or even with statistical agencies of counterpart economies may not be feasible due to confidentiality or legal constraints. The envisaged increase in data flow with more granular information requires substantial work in several areas, including on confidentiality and legal issues. In this context, the new recommendation on promotion of data sharing of the Second Phase of the G-20 Data Gaps Initiative (DGI-2) (recommendation II.20) was welcomed by the G-20 economies to facilitate sharing the experiences with exchanges of granular data and identifying ways to overcome existing barriers as well as to strengthen the linkages and consistencies between datasets. Some economies conduct bilateral exchanges of micro data through bilateral agreements or contracts to preserve confidentiality. For this purpose, some economies request prior authorization from reporters.

Data exchange can also be done at more aggregated levels posing less confidentiality issues. In this regard, the granularity of CDIS data with breakdowns by instrument (net equity and net debt), further breakdowns of net debt instruments into gross assets and gross liabilities, and the separate identification of positions between fellow enterprises provides a wide range for analysis. ${ }^{9}$

\section{Metadata Exchange}

Metadata exchange has also proved to be an important and useful way for identifying and analyzing the reasons for asymmetries. Various economies collaborate with their main counterparts to enhance their understanding of each other's direct investment compilation systems, by conducting professional exchanges with the officials responsible for the compilation and dissemination of direct investment statistics.

The results of the CDIS metadata questionnaire (available at the CDIS website) provide detailed information on the collection and compilation practices adopted by CDIS reporting economies. They are an important source of information for assessing data quality and deviations from recommended standards and have been used to explain some of the bilateral asymmetries in this paper. The structured design of the metadata questionnaires allows easy cross-economy comparisons, facilitating the identification of methodological differences with main counterparts. The questionnaires also include compilers' contact data to facilitate information exchange with main counterparts. Methodological comparability is improving over time with the implementation of the international standards set in the BPM6 and the 2015 CDIS Compilation Guide, but there are areas were practices vary (see Annex VII).

\footnotetext{
${ }^{9}$ OECD's FDI database contains as well very valuable information on bilateral DI positions, transactions, and income (See OECD.Stat).
} 


\section{Specific Planned Actions to Reduce Asymmetries}

The reduction of asymmetries has always been a challenge for national compilers. First, it is time consuming and resource intensive for economies to identify the specific reasons and even more to address the asymmetries. Second, solving asymmetries in one item may create new asymmetries in another one. Therefore, investigating topics that are closely linked and the consistent recording of external positions is essential to reduce asymmetries. It is also of importance ensuring consistency between external sector statistics and other statistical domains, mainly national accounts, and linking asymmetries arising from both data sets.

\section{Planned by CDIS Participants}

Economies involved in bilateral asymmetries exercises conducted by STA reported on their specific planned actions to reduce asymmetries. As part of the second exercise of the CDIS bilateral asymmetries ${ }^{10}$ conducted in 2016, STA consulted with 47 CDIS participating economies on any plans to implement specific actions or changes in the collection and/or compilation process to reduce their asymmetries. Annex VIII shows a summary of the main actions they reported. Main categories of planned actions include: continue analyzing the reasons for discrepancies on an aggregated level; more active bilateral consultations and interaction with counterparts; more active participation in the FDI Network (European countries); continued work to develop the European Group Register; revisions to CDIS data; and enhancements in the reporting systems and improvements in data sources.

\section{Ongoing Initiatives by International Organizations}

In addition, there are various initiatives led by international organizations to facilitate bilateral meetings between countries interested in discussing asymmetries in their direct investment statistics. $O E C D$ organizes bilateral asymmetry meetings adjacent to the Working Group on International Investment Statistics (WGIIS) meetings. Eurostat facilitates platforms for bilateral asymmetry meetings. In addition, the $I M F$, with the support of Bundesbank, will conduct a workshop for CDIS compilers aimed at reducing asymmetries in November 2017.

Work ahead to facilitate data exchange include following up on the possibility of Eurostat sharing the infrastructure of the FDI Network to expand it at world level (see IMF, BOPCOM 16/18).

Work ahead on the CDIS metadata questionnaire include:

- Enhancements to the questionnaire through the addition of new specific questions on bilateral asymmetries, for example on main reasons that explain asymmetries for specific counterpart countries, instruments (equity/debt), type of investments, or

\footnotetext{
${ }^{10}$ See Work on Bilateral Asymmetries in the Coordinated Direct Investment Survey: Paper by IMF (BOPCOM 16/10).
} 
sectors involved; future or current work to address/understand/reduce them; links to any related publication on the research conducted in this area by the compiling agency, etc.; and

- Continued efforts to encourage economies to update and fine-tune metadata information as needed, to account for most up to date information on any possible methodological differences across countries that could explain asymmetries.

The steps taken to increasing awareness of the asymmetries and understanding the reasons that explain them are, per se, an important achievement, even if it is not feasible to reduce them. 


\section{REFERENCES}

Data on Special Purpose Entities: Compilation and Dissemination-Russian Experience (IMF, BOPCOM 16/21)

Developing CDIS Granular Data- Central Bank of the Russian Federation (BOPCOM 15/10.b)

European Networking Exercises: The FDI Network: Report by ECB/Eurostat (BOPCOM 14/20)

IMF (2009), Balance of Payments and International Investment Position Manual, Sixth Edition (BPM6).

IMF (2014), Balance of Payments and International Investment Position Compilation Guide, $(B P M 6 C G)$.

IMF (2014), Coordinated Direct Investment Survey (CDIS): Project on Bilateral Asymmetries.

IMF (2015), The Coordinated Direct Investment Survey Guide - 2015 (CDIS Guide).

OECD (2008), OECD Benchmark Definition of Foreign Direct Investment, Fourth Edition (BMD4).

Second Phase of the G-20 Data Gaps Initiative (DGI-2) First Progress Report

Summary of the Outcomes of the Committee's Discussions (BOPCOM 16/18)

Work on Bilateral Asymmetries in the Coordinated Direct Investment Survey: Paper by IMF (BOPCOM 16/10)

Work on Bilateral Asymmetries in CDIS- Philippines' Experience (BOPCOM 16/27)

BOP and IIP database (Link)

CDIS database (CDIS Database) and CDIS metadata (CDIS Metadata) 


\section{ANNEX I. MirRor DATA}

\section{Usefulness and Limitations of Derived Data}

Direct investment positions by counterpart economy available at the CDIS allow for a comparison between data reported by one economy and mirror data reported by its counterpart CDIS reporting economies. Mirror information can be used to calculate derived data for direct investment. Derived data could be lower or higher than the CDIS data reported by a specific compiling economy. When reported data and derived data substantially differ, efforts are made to explain such differences and to address them, if feasible. Differences are often spread among several counterpart economies or concentrated in a limited number of counterparts. Differences can be explained due to bilateral asymmetries or because some relevant counterparts of the compiling economy may not participate in the CDIS, or provide data as confidential. If reported data by a given economy are lower than derived data, it can suggest under coverage.

Usefulness. Mirror data are a useful source of information for economies that do not compile direct investment positions (or compile direct investment with no counterpart economy detail) as they can give insights of their total inward and outward direct investment positions with breakdown by counterpart economy and can complement other data sources. In addition, the comparison between reported and derived data may be useful for economies that do compile direct investment data to cross-check and verify their own estimates and to highlight data gaps or errors, or identify areas for improvement.

Limitations. When using derived measures of direct investment, users should note that differences with actual data (reported or not) arise not only due to bilateral asymmetries between reporting economies. For example, some relevant counterparts of the compiling economy may not participate in the CDIS, or may not provide data for such economy due to confidentiality, or because these data fall below a reporting threshold. Therefore, the use of derived data should be done with caution. 


\section{ANNEX II. FELLOW ENTERPRISES}

Fellow enterprises are enterprises under the control or influence of the same immediate or indirect investor but neither fellow enterprise controls or influences the other fellow enterprise (BPM6. Paragraph $6.17 \mathrm{c}$ ).

International guidelines establish that direct investment positions between fellow enterprises should be recorded in the CDIS based on the extended directional principle and, only when the residence of the UCP is unknown, these positions should be recorded on an assets liabilities basis.

Compilation methods (CDIS Guide, paragraph 4.10)

- $\quad$ The extended directional principle implies that "both asset and liability positions between fellow enterprises are to be recorded in outward direct investment when the ultimate controlling parent is a resident, and in inward direct investment when the UCP is a nonresident".

- The assets liabilities principle implies "to record assets of a resident fellow enterprise on a nonresident fellow enterprise in outward direct investment, and to record liabilities of a resident fellow enterprise to a nonresident fellow enterprise in inward direct investment".

Most CDIS reporters (around 85 percent) include direct investment positions with fellow enterprises in their total inward and outward direct investment positions and nearly half provide separate data on fellows. The CDIS metadata questionnaire shows that 50 percent of the CDIS reporters record direct investment positions with fellow enterprises abroad using the extended directional principle and around 30 percent of the economies apply the assets liabilities principle. 


\section{AnNeX III. ASYMmetries in DATA BetWeEn Fellows}

This annex presents two scenarios: (a) when the ultimate controlling parent (UCP) is nonresident for both economies that is, it is resident in a third economy; and (b) when one economy collects consolidated data from local enterprise groups (LEGs).

(a) When the UCP is nonresident (additional examples to Section V, A)

\section{Table 9. Asymmetries when the Ultimate Controlling Parent is Nonresident for Both} Economies as of end-2015

(US Dollars, millions)

\begin{tabular}{|l|l|c|c|c|c|}
\hline $\begin{array}{c}\text { Reporting } \\
\text { Economy }\end{array}$ & $\begin{array}{c}\text { Counterpart } \\
\text { economy }\end{array}$ & $\begin{array}{c}\text { Outward DI (Net) } \\
\text { with Fellows, } \\
\text { reported by the } \\
\text { reporting economy }\end{array}$ & $\begin{array}{c}\text { Inward DI (Net) } \\
\text { with Fellows, } \\
\text { reported by the } \\
\text { counterpart } \\
\text { economy }\end{array}$ & $\begin{array}{c}\text { Diff. } \\
\text { Outward - } \\
\text { Inward }\end{array}$ & $\begin{array}{c}\text { Total } \\
\text { Difference }\end{array}$ \\
\hline Poland & Spain & 883 & 3,395 & $\mathbf{- 2 , 5 1 2}$ & $\mathbf{2 , 7 3 7}$ \\
\hline Spain & Poland & -385 & $-3,122$ & & $\mathbf{2 2 5}$ \\
\hline Total Difference & Sweden & 146 & $-1,235$ & $\mathbf{1 , 3 8 1}$ & \\
\hline Germany & Sermany & 114 & 1,372 & $\mathbf{- 1 , 2 5 8}$ & \\
\hline Sweden & German & & $\mathbf{1 2 3}$ \\
\hline Total Difference
\end{tabular}

Source IMF CDIS, 2016 release

Table 9 shows two examples of this type of asymmetry. The four countries included in this table record direct investment positions between fellow enterprises using the extended directional principle, according to their responses to the CDIS metadata questionnaire. The first example shows the positions between enterprises resident in Poland and their fellow enterprises resident in Spain. Both countries record a larger amount, in absolute value, under inward than under outward, because the ultimate controlling parents should be resident in a third economy (different than Poland or Spain). The difference between outward between fellow enterprises reported by Poland in Spain and inward between fellow enterprises reported by Spain from Poland is very large ( $\$ 2.5$ billion) and it is similar to the difference between the mirror values, that is, outward reported by Spain in Poland and the inward reported by Poland from Spain ( $\$ 2.7$ billion). In this case, when comparing the total net direct investment (outward minus inward) of one economy against the other, the bilateral asymmetry drops to $\$ 0.2$ billion. The same occurs with the asymmetry on direct investment positions with fellow enterprises between Germany and Sweden; when comparing the total net values, the difference drops from around $\$ 1.2$ billion to $\$ 0.1$ billion. 


\section{(b) When one economy collects consolidated data from local enterprise groups}

When one economy collects consolidated data from local enterprise groups (LEGs), bilateral asymmetries can arise in the component: "direct investment between fellow enterprises" but bilateral asymmetries in total direct investment will not be affected.

\section{What is a Local Enterprise Group?}

Local (or territory-specific) enterprise group refers to an investor and the legal entities under that investor that are resident in the reporting economy (BPM6, paragraph 4.55).

Some economies collect consolidated direct investment data from the resident parent companies. In this case, direct investment positions of the affiliated units, that are resident in the compiling economy, are consolidated into a single enterprise and they are referred to as a local enterprise group (LEGs).

The local enterprise group consolidates data from the resident direct investor (or direct investment enterprise) with the data from its subsidiaries that could be fellow enterprises of nonresident companies. The consolidated data are recorded as outward if the reporting company is the direct investor or as inward if the reporting company is the direct investment enterprise, and in both cases, no values are recorded under "direct investment between fellow enterprises".

When one economy collects its data through local enterprise groups and its counterpart economy collects data from individual enterprises, there could be bilateral asymmetries when compiling data between fellow enterprises.

\section{Example}

If fellow enterprise A is resident in economy A, which collects consolidated data from a local enterprise group (the reporting enterprise is the direct investor of the nonresident company) and its fellow enterprise B is resident which collects data from individual

If enterprise A provides a loan to enterprise $\mathrm{B}$, economy $\mathrm{A}$ will record this loan under total outward direct investment and will not include any value under "direct investment in economy B, enterprises.

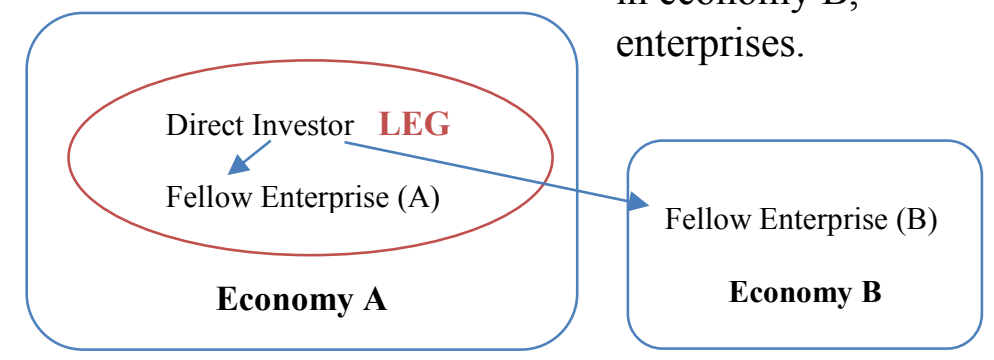
between fellow enterprises" because consolidated data do not identify separate data for each enterprise which are part of the group, and economy B will record this loan under inward direct investment between fellow enterprises.

In this case, there would be a bilateral asymmetry between outward with fellow enterprises recorded by economy A (null) and inward with fellow enterprises recorded by economy B, 
but at aggregated level there would be no asymmetries; total outward reported by economy A would be consistent with total inward reported by economy $\mathrm{B}$.

Table 10. Asymmetries when One Economy Collects Data from LEGs as of end-2015

(US Dollars, millions)

\begin{tabular}{|l|l|c|c|c|c|c|c|}
\hline $\begin{array}{l}\text { Reporting } \\
\text { Economy }\end{array}$ & $\begin{array}{c}\text { Counterpart } \\
\text { economy }\end{array}$ & $\begin{array}{c}\text { Outward } \\
\text { with Fellows, } \\
\text { reported by } \\
\text { the reporting } \\
\text { economy }\end{array}$ & $\begin{array}{c}\text { Inward with } \\
\text { Fellows, } \\
\text { reported by } \\
\text { the } \\
\text { counterpart } \\
\text { economy }\end{array}$ & $\begin{array}{c}\text { Diff. }= \\
\text { Outward } \\
\text { with fellows }- \\
\text { Inward with } \\
\text { fellows }\end{array}$ & $\begin{array}{c}\text { Outward } \\
\text { reported by } \\
\text { the } \\
\text { reporting } \\
\text { economy }\end{array}$ & $\begin{array}{c}\text { Inward } \\
\text { reported } \\
\text { by the } \\
\text { counterpar } \\
\text { t economy }\end{array}$ & $\begin{array}{c}\text { Diff. = } \\
\text { Outward } \\
\text { - Inward }\end{array}$ \\
\hline Netherlands & Slovak Republic & & $-1,334$ & 1,334 & 8,487 & 8,536 & -50 \\
\hline
\end{tabular}

Table 10 shows an example when one economy collects data from local enterprise groups. In this case, the Netherlands collects consolidated direct investment data from local enterprise groups and Slovak Republic collects direct investment data from individual enterprises. The table shows that the former does not report any values on direct investment between fellow enterprises (the local enterprise group consolidates the data from all affiliated resident companies and does not identify the transactions or positions undertaken by fellow enterprises) which implies large asymmetries arising in this component (US\$1.4 billion).

When comparing, total outward DI reported by the Netherlands with total inward reported by Slovak Republic, the bilateral difference decreases from more than \$1 billion to almost zero as shown in table 10.

When one economy compile direct investment data from LEGs, the CDIS bilateral asymmetries should be analyzed at aggregated level (total inward vs. total outward) to eliminate asymmetries produced in the component "direct investment between fellow enterprises". 


\section{Annex IV. Special Purpose Entities}

\section{Why Should SPEs Data Be Included in the CDIS?}

SPEs are entities that channel a large amount of funds between entities outside the economy in which they are located and have little presence in the host economy. The creation of SPEs affects direct investment since these structures, generally located in countries offering tax or other advantages, generate cross border transactions and positions between subsidiaries located in different countries and are an important instrument in multinational enterprises organization. For these entities, most assets and liabilities are with nonresidents. SPEs are often used as devices to raise capital or to hold assets and liabilities and usually do not undertake significant production. Usually they have little or no physical presence and the funds they transfer may have limited impact on the local economy.

These units are to be included in the direct investment statistics of an economy even though the funds they transfer and the positions they hold may have little impact on the local economy. The funds are an integral part of a direct investor's financial transactions and positions with affiliated enterprises; excluding these funds from direct investment would distort and substantially understate direct investment financial flows and positions at aggregate levels. On the other hand, the inclusion of these data in direct investment promotes symmetry and consistency among economies.

\section{How can SPEs be identified? ${ }^{11}$}

- The enterprise is a legal entity, formally registered with a national authority and subject to fiscal and other legal obligations in the economy in which it is resident;

- The enterprise is ultimately controlled by a nonresident parent company, either directly or indirectly;

- The enterprise has few or no employees, little or no production in the host economy, and little or no physical presence;

- Almost all the assets and liabilities of the enterprise represent investments in or from other economies; and

- The core business of the enterprise consists of group financing or holding activities, this is, they channel funds from nonresidents to other nonresidents. However, in its daily activities, managing and directing plays only a minor role.

${ }^{11}$ OECD Benchmark Definition- BD4 


\section{ANNEX V. ECONOMies REPORTING DATA ON FELlOW ENTERPRISES TO THE CDIS}

\section{Inward direct investment}

The table below shows the top 15 inward economies that report data for fellows, ranked per the size of their total investment. For all economies reporting fellow enterprises data for inward, positions with fellow enterprises represent 2 percent of total inward direct investment $^{12}$. The highest percentage corresponds to Belgium (40 percent in absolute terms), followed by Mexico (12.7 percent). The lowest percentages correspond to Switzerland ( 0.6 percent in absolute terms and Mauritius with 0.8 percent).

Table 11-A. Inward Direct Investment Positions - Economies Reporting 2015 Data for Fellow Enterprises

(US Dollars, millions)

\begin{tabular}{|c|c|c|c|c|c|c|c|c|c|}
\hline & \multirow{3}{*}{$\begin{array}{c}\text { Total } \\
\text { Inward } \\
\mathbf{a}=\mathbf{b}+\mathbf{c}\end{array}$} & \multirow{3}{*}{$\begin{array}{l}\text { Equity } \\
\text { (Net) } \\
\text { b }\end{array}$} & \multirow{3}{*}{$\begin{array}{c}\text { Debt (Net) } \\
c=d-e\end{array}$} & \multirow{3}{*}{$\begin{array}{l}\text { Debt } \\
\text { Liabilities } \\
\text { (Gross) } \\
\text { d }\end{array}$} & \multirow{3}{*}{$\begin{array}{c}\text { Debt } \\
\text { Assets } \\
\text { (Gross) } \\
\text { e }\end{array}$} & \multirow{3}{*}{$\begin{array}{c}\text { Of Which, } \\
\text { Inward (Net) } \\
\text { with Fellow } \\
\text { Enterprises } \\
\text { f=g - h }\end{array}$} & \multicolumn{2}{|c|}{$\begin{array}{l}\text { Equity plus debt with } \\
\text { fellow enterprises }\end{array}$} & \multirow{3}{*}{$\begin{array}{l}\% \\
\mathrm{f} / \mathrm{a}\end{array}$} \\
\hline & & & & & & & $\begin{array}{l}\text { Liabilities } \\
\text { (Gross) }\end{array}$ & $\begin{array}{l}\text { Assets } \\
\text { (Gross) }\end{array}$ & \\
\hline & & & & & & & $\mathrm{g}$ & $\mathrm{h}$ & \\
\hline $\begin{array}{r}\text { United } \\
\text { Kingdom }\end{array}$ & $1,554,303$ & $1,426,215$ & 128,088 & 246,925 & 118,837 & 16,989 & 18,965 & 1,977 & 1.1 \\
\hline $\begin{array}{l}\text { China, P.R.: } \\
\text { Hong Kong }\end{array}$ & $1,394,580$ & $1,369,491$ & 25,089 & 148,281 & 123,192 & $-32,108$ & 61,560 & 93,669 & 2.3 \\
\hline Ireland & 866,218 & 594,503 & 271,714 & 656,477 & 384,763 & 37,513 & 314,684 & 277,171 & 4.3 \\
\hline Switzerland & 862,624 & 846,048 & 16,576 & 166,100 & 149,523 & $-4,749$ & 86,123 & 90,872 & 0.6 \\
\hline Germany & 786,941 & 589,849 & 197,092 & 372,738 & 175,647 & 99,318 & 208,770 & 109,452 & 12.6 \\
\hline France & 660,107 & 626,559 & 33,548 & 179,829 & 146,281 & 20,322 & 124,052 & 103,730 & 3.1 \\
\hline Spain & 546,803 & 456,936 & 89,867 & 144,207 & 54,338 & 54,312 & 87,835 & 33,522 & 9.9 \\
\hline Mexico & 509,292 & 397,520 & 111,772 & 162,861 & 51,089 & 64,570 & 103,779 & 39,209 & 12.7 \\
\hline Brazil & 460,381 & 392,577 & 67,804 & 85,658 & 17,854 & 40,283 & 40,283 & & 8.7 \\
\hline Belgium & 455,366 & 624,393 & $-169,027$ & 283,088 & 452,115 & $-181,194$ & 174,700 & 355,895 & 39.8 \\
\hline Italy & 337,083 & 302,579 & 34,505 & 86,592 & 52,088 & 4,065 & 33,264 & 29,199 & 1.2 \\
\hline Sweden & 289,518 & 237,229 & 52,288 & 93,310 & 41,022 & 28,275 & 38,666 & 10,391 & 9.8 \\
\hline Mauritius & 269,105 & 169,065 & 100,041 & 100,053 & 12 & $-2,040$ & 10,628 & 12,668 & 0.8 \\
\hline Austria & 261,349 & 250,833 & 10,516 & 41,241 & 30,725 & 9,089 & 31,244 & 22,154 & 3.5 \\
\hline $\begin{array}{r}\text { Russian } \\
\text { Federation }\end{array}$ & 257,287 & 201,342 & 55,945 & 65,021 & 9,075 & 25,833 & 26,580 & 747 & 10.0 \\
\hline $\begin{array}{r}\text { All other } \\
\text { economies } \\
\text { reporting } \\
\text { fellows' data }\end{array}$ & $2,225,455$ & $1,845,340$ & 380,111 & 592,015 & 211,908 & 48,891 & 163,129 & 114,242 & 2.2 \\
\hline $\begin{array}{l}\text { Total reporting } \\
\text { fellows' data }\end{array}$ & $11,736,412$ & $10,330,478$ & $1,405,929$ & $3,424,397$ & $2,018,469$ & 229,369 & $1,524,262$ & $1,294,898$ & 2.0 \\
\hline World & $28,405,605$ & $23,075,491$ & $3,750,588$ & $5,991,193$ & $2,701,123$ & 229,369 & $1,524,262$ & $1,294,898$ & 0.8 \\
\hline
\end{tabular}

Source IMF's CDIS, 2016 release

Economies listed are those that separately identify fellows' data.

Fellow enterprises' data are an of which item of total inward.

\section{Outward Direct Investment}

\footnotetext{
${ }^{12}$ Percentages for inward and outward data are calculated based on net figures (following the directional principle and netting liabilities and assets). Weights for gross liabilities and assets would be higher.
} 
The table below shows the top 15 outward economies that report data for fellows, ranked per the size of their total investment. For all economies reporting fellow enterprises data for outward, positions with fellow enterprises represent 0.7 percent of total outward investment. The highest percentages correspond to Spain, with a 4.4 percent in absolute terms, followed by Republic of Korea, and Russian Federation, with 4.3 and 4.2 percent respectively. The lowest percentages correspond to Cyprus, Switzerland, and China, P.R.: Hong Kong with percentages rounded to 0.0 percent.

Table 11-B. Outward Direct Investment Positions - Economies Reporting 2015 Data for Fellow Enterprises

(US Dollars, millions)

\begin{tabular}{|c|c|c|c|c|c|c|c|c|c|}
\hline & \multirow[t]{2}{*}{$\begin{array}{c}\text { Total } \\
\text { Outward }\end{array}$} & \multirow[b]{2}{*}{ Equity(Net) } & \multirow[b]{2}{*}{$\begin{array}{l}\text { Debt } \\
\text { (Net) }\end{array}$} & \multirow[b]{2}{*}{$\begin{array}{l}\text { Debt } \\
\text { Assets } \\
\text { (Gross) }\end{array}$} & \multirow[b]{2}{*}{$\begin{array}{l}\text { Debt } \\
\text { Liabilities } \\
\text { (Gross) }\end{array}$} & \multirow{2}{*}{$\begin{array}{c}\text { Of Which, } \\
\text { Outward } \\
\text { (Net) with } \\
\text { Fellow } \\
\text { Enterprises }\end{array}$} & \multicolumn{2}{|c|}{$\begin{array}{l}\text { Equity plus debt with } \\
\text { fellows }\end{array}$} & \multirow[b]{2}{*}{$\%$} \\
\hline & & & & & & & $\begin{array}{c}\text { Assets } \\
\text { (Gross) } \\
\text { with Fellow } \\
\text { Enterprises }\end{array}$ & $\begin{array}{l}\text { Liabilities } \\
\text { (Gross) } \\
\text { with Fellow } \\
\text { Enterprises }\end{array}$ & \\
\hline & $\mathbf{a}=\mathbf{b}+\mathbf{c}$ & B & $c=d-e$ & $\mathrm{~d}$ & $\mathrm{e}$ & $\mathbf{f}=\mathbf{g}-\mathbf{h}$ & $\mathrm{g}$ & $\mathrm{h}$ & f/a \\
\hline $\begin{array}{l}\text { China, P.R.: } \\
\text { Hong Kong }\end{array}$ & $1,383,586$ & $1,207,413$ & 176,173 & 228,656 & 52,482 & 559 & 3,435 & 2,876 & 0.0 \\
\hline Germany & $1,376,181$ & $1,473,916$ & $-97,735$ & 294,267 & 392,002 & $-6,805$ & 31,173 & 37,978 & 0.5 \\
\hline France & $1,198,770$ & $1,156,723$ & 42,047 & 264,103 & 222,056 & 32,814 & 180,356 & 147,542 & 2.7 \\
\hline Switzerland & $1,113,081$ & 990,120 & 122,961 & 349,219 & 226,257 & -356 & 21,974 & 22,331 & 0.0 \\
\hline Ireland & 887,510 & 794,189 & 93,321 & 217,694 & 124,373 & 14,864 & 21,728 & 6,864 & 1.7 \\
\hline Spain & 490,332 & 529,242 & $-38,910$ & 57,527 & 96,437 & $-21,688$ & 17,294 & 38,982 & 4.4 \\
\hline Italy & 467,300 & 464,199 & 3,101 & 70,932 & 67,832 & $-2,696$ & 8,091 & 10,787 & 0.6 \\
\hline Belgium & 446,237 & 414,148 & 32,089 & 76,470 & 44,381 & 8,630 & 38,548 & 29,921 & 1.9 \\
\hline Sweden & 357,133 & 329,042 & 28,092 & 89,887 & 61,795 & 2,158 & 21,647 & 19,489 & 0.6 \\
\hline Austria & 309,993 & 281,495 & 28,498 & 35,934 & 7,436 & 10,809 & 15,241 & 4,432 & 3.5 \\
\hline $\begin{array}{r}\text { Russian } \\
\text { Federation }\end{array}$ & 286,583 & 282,099 & 4,484 & 79,322 & 74,839 & 12,128 & 13,201 & 1,074 & 4.2 \\
\hline $\begin{array}{c}\text { Korea, } \\
\text { Republic of }\end{array}$ & 271,581 & 233,033 & 38,548 & 41,361 & 2,813 & 11,758 & 12,031 & 273 & 4.3 \\
\hline Mauritius & 221,313 & 173,915 & 47,397 & 57,792 & 10,395 & 2,013 & 12,639 & 10,626 & 0.9 \\
\hline Denmark & 178,893 & 155,092 & 23,801 & 51,663 & 27,863 & 515 & 660 & 145 & 0.3 \\
\hline Cyprus & 174,029 & 159,235 & 14,794 & 15,331 & 538 & 25 & 25 & 0 & 0.0 \\
\hline $\begin{array}{r}\text { All other } \\
\text { economies } \\
\text { reporting } \\
\text { fellows'data }\end{array}$ & 665,829 & 648,656 & 17,172 & 121,716 & 104,544 & 2,074 & 31,894 & 29,817 & 0.3 \\
\hline $\begin{array}{r}\text { Total } \\
\text { reporting } \\
\text { fellows'data }\end{array}$ & $\mathbf{9 , 8 2 8 , 3 5 2}$ & $9,292,519$ & 535,832 & $2,051,875$ & $1,516,042$ & 66,801 & 429,938 & 363,136 & 0.7 \\
\hline World & $28,244,188$ & $25,165,725$ & $2,200,781$ & $4,682,433$ & $2,742,392$ & 66,801 & 429,938 & 363,136 & 0.2 \\
\hline
\end{tabular}

Source IMF's CDIS, 2016 release

Economies listed are those that separately identify fellows' data.

Fellow enterprises' data is an of which item of total outward. 


\section{AnNex VI. Top Economies Reporting UnAllocated oR CONFIDENTIAL Data}

This analysis shows that 53 percent of the total "Not specified (including confidential)" for inward direct investment positions is concentrated in the top 16 economies listed in Table 12-A and 46 percent of the total "Not specified (including confidential)" for outward direct investment is concentrated in the top 10 economies listed in Table 12-B.

Table 12-A. Not Specified over Total Inward Direct Investment for Individual Economies as of end-2015

(US Dollars, millions)

\begin{tabular}{|l|r|r|r|}
\hline & $\begin{array}{c}\text { Total } \\
\text { World }\end{array}$ & $\begin{array}{c}\text { Not Specified } \\
\text { (including } \\
\text { Confidential) }\end{array}$ & $\begin{array}{c}\text { \%of } \\
\text { Total } \\
\text { World }\end{array}$ \\
\hline Malta & 165,718 & 161,627 & $98 \%$ \\
\hline Cyprus & 173,709 & 121,374 & $70 \%$ \\
\hline Kuwait & 14,604 & 7,048 & $48 \%$ \\
\hline Nepal & 905 & 433 & $48 \%$ \\
\hline Bhutan & 167 & 67 & $40 \%$ \\
\hline Cabo Verde & 1,617 & 631 & $39 \%$ \\
\hline Kosovo, Republic of & 3,543 & 1,363 & $38 \%$ \\
\hline West Bank and Gaza & 2,511 & 960 & $38 \%$ \\
\hline Austria & 261,349 & 97,048 & $37 \%$ \\
\hline Uruguay & 21,750 & 7,587 & $35 \%$ \\
\hline Montenegro & 4,570 & 1,284 & $28 \%$ \\
\hline Chile & 212,990 & 56,719 & $27 \%$ \\
\hline Albania & 4,275 & 1,113 & $26 \%$ \\
\hline Switzerland & 862,624 & 168,826 & $20 \%$ \\
\hline Australia & 537,352 & 102,049 & $19 \%$ \\
\hline Malaysia & 117,644 & 18,920 & $16 \%$ \\
\hline Top 16 economies & $2,385,328$ & 747,049 & $31 \%$ \\
\hline All other Economies & $26,020,277$ & 667,848 & $3 \%$ \\
\hline World & $28,405,605$ & $1,414,897$ & $5 \%$ \\
\hline Source & $2016 r e l e a s$ & & \\
\hline
\end{tabular}

Source IMF's CDIS, 2016 release
Table 12-B. Not Specified over Total Outward Direct Investment for Individual Economies as of end-2015

(US Dollars, millions)

\begin{tabular}{|l|r|r|r|}
\hline & $\begin{array}{c}\text { Total } \\
\text { World }\end{array}$ & $\begin{array}{c}\text { Not Specified } \\
\text { (including } \\
\text { Confidential) }\end{array}$ & $\begin{array}{c}\text { \% of } \\
\text { Total } \\
\text { World }\end{array}$ \\
\hline Malta & 67,013 & 66,669 & $99 \%$ \\
\hline Cyprus & 174,029 & 127,729 & $73 \%$ \\
\hline Armenia, Republic of & 228 & 134 & $59 \%$ \\
\hline China, P.R.: Macao & 3,095 & 1,759 & $57 \%$ \\
\hline Australia & 396,432 & 148,090 & $37 \%$ \\
\hline Malaysia & 136,892 & 49,361 & $36 \%$ \\
\hline Austria & 309,993 & 109,847 & $35 \%$ \\
\hline Chile & 92,597 & 24,581 & $27 \%$ \\
\hline Lithuania & 2,610 & 513 & $20 \%$ \\
\hline Slovak Republic & 2,370 & 413 & $17 \%$ \\
\hline Top 10 economies & $1,185,257$ & 529,096 & $45 \%$ \\
\hline All other Economies & $27,058,931$ & 646,561 & $2 \%$ \\
\hline World & $28,244,188$ & $1,175,657$ & $4 \%$ \\
\hline
\end{tabular}

Source IMF's CDIS, 2016 release 


\section{ANNEX VII. INFORMATION INCLUDED IN THE CDIS MeTADATA QUESTIONNAIRE}

i. Contact information of the reporting economy and information about the website used for disseminating direct investment data;

ii. Data sources and collection methods including information on whether data sources for direct investment are based on a sample or a census (with detail by sectors), the primary and secondary source(s) of information used in building the sample frame or census of resident direct investment enterprises /direct investors, the reporting threshold applied (indicating if direct investment data below the threshold are estimated), the source(s) of information used to collect CDIS data, the method, if any, used in estimating data for nonresponding units, and whether CDIS data refer to calendar or fiscal year;

iii. Valuation principles for equity investments (listed and unlisted) and for debt instruments (debt securities and other debt instruments); whether accrued interest is included in the valuation of debt instruments; and if the exchange rate at the end of the period is used to estimate positions for financial instruments denominated in a foreign currency;

iv. Other specific compilation issues such as coverage of flexible corporate structures with little or no physical presence, whether the reporting unit is an enterprise or a local enterprise group, whether positions of/with fellow enterprises are recorded on a straight Asset/Liability basis or depending on the residence of the UCP, information on how economies determine UCP, the method used to determine direct investment relationships, whether direct investment in real estate is included or no, and whether debt (including permanent debt) between selected affiliated financial corporations is included in or excluded from direct investment;

v. Questions to assess consistency of CDIS data with the IIP. 


\section{Annex VIII. ACtions to ReduCE ASYMmetries}

\section{CDIS Participants: Specific Planned Actions to Reduce Asymmetries}

Continue analyzing the reasons for discrepancies on an aggregated level. More active bilateral consultations and interaction with counterparts.

Participation in the FDI Network (European countries)

- Continue participation in the general annual exercise of the FDI Network.

- Participate more actively.

- Send more data on direct investment positions via the FDI network, more especially for the EU countries and instruments with the highest asymmetries.

- Share the major identified asymmetries and discuss them at a micro-level data with the counterpart.

\section{European Group Register}

- Continue work in progress, which will ensure that all EU countries in the future will have the same information on enterprise group structures when creating sample frames for direct investment surveys.

\section{Revisions to CDIS data}

- Revise CDIS data as soon as annual direct investment survey results become available.

- Transmit more regularly revised version of CDIS to IMF, in accordance with national revision and dissemination practices for direct investment.

- Revise CDIS full time series data according to new methodological standards.

Enhance reporting systems and improve data sources

- Address methodological issues.

- Address misreporting and adjust figures accordingly.

- Establish a mechanism to identify the counterpart economy in the case of SPEs.

- Address lack of data coverage.

- Apply new methods for the non-sample under coverage.

- Improve collection methods and estimation techniques for intercompany loans.

- Apply more rigorous validations and editing during processing of data.

- Contact more actively the survey respondents to provide guidance on reporting in complex cases.

- Improve information by counterpart economy particularly regarding the identification of the immediate counterpart (without looking through enterprises in the middle of an ownership chain) and in cases of complex organizational structures.

- Examine possible under coverage due to misclassifications with portfolio investment. 